\title{
French Green Growth Paradigm In-line with EU Targets Towards Sustainable Development Goals
}

\author{
Dr. Aung $\mathrm{Ze} \mathrm{Ya}^{1 *}$
}

\begin{abstract}
:
The novel aspect of this article is the integrative orchestration of recently Green Strategies of Global, Europe and French Fight against Climate Change Challenge as well as comprehensive analysis on the French RE (Renewable Energy) Scenarios during 2006 to 2015. The contributions of French RE Capacities are evidently compared with respect to World and European Union (EU). Moreover, French Icons of Green Growth, the present situation and emerging RE Trends in the near future are highlighted in this research paper.

United Nations (UN) is encouraging a Sustainable World for all initiative to ensure universal access to save the World by decarbonization, promote the harnessing of RE energies and improve Energy Efficiency (EE). As the western powerful organization, EU is obviously participating in UN's Green Efforts and also leading the strategic fight against the Climate Change Battle.

France is actively addressing the Climate Change and delegable attending Paris 2015 (COP 21). France is significantly one of the few World developed countries that is facilitated with high living standard and clean electricity generation as the leader of EU electricity exporter. France has concrete frameworks and impressive policies for RE development and effectively boosting it with incentive mechanisms. There is no doubt that French Green Growth Paradigm is shifting with implementation of Low-carbon Economy towards Sustainable Future of Mother Earth.
\end{abstract}

Key Words: Climate Change, French RE, EU, Paris 2015, SDGs, PV

\section{Introduction}

\subsection{Introduction to $\mathrm{RE}$}

Globally, the largest amount of Greenhouse Gases (GHGs) is significantly emitted from fossil fuels (coal, oil and gas) utilizations for Electricity Generations. As the undesirable outcomes, Global Warming and Climate Change is becoming Global No.1 Problem. Realistically, Renewable Energy (RE) has inherent Sustainability by their reliance upon infinitely available resources that are naturally recharging, clean, ecofriendly, zero fuel cost. To penetrate Greenhouse Effect layer and create better ecosystem for next generations of the human being, RE Promotion is the predominant backbone of all strategies towards Sustainable Future of Mother Earth that are summarized and demonstrated in Fig.1.

RE provided an estimated $19.1 \%$ of global final energy consumption in the year 2013. RE growth is significantly driven by supportive policies and the increasing costcompetiveness. By the end of the year 2014, RE comprised an estimated $27.7 \%$ of the world's power generating capacity, enough to supply an estimated $22.8 \%$ of Global electricity [1]. Hydropower, Solar PV and Wind dominated in RE market. IRENA's analysis shows that Global annual investment in RE can reach US\$900 billion by the year 2030 [4].

This research work was performed during the ERASMUS MUNDUS Action 2 Scholarship: PostDoctorate Research Fellowship Program at University of Nice-Sophia Antipolis in Nice- FRANCE;

1 Professor, Department of Electrical Power Engineering, Mandalay Technological University, MandalayMYANMAR (Email: dr.aungzeya010@gmail.com) 


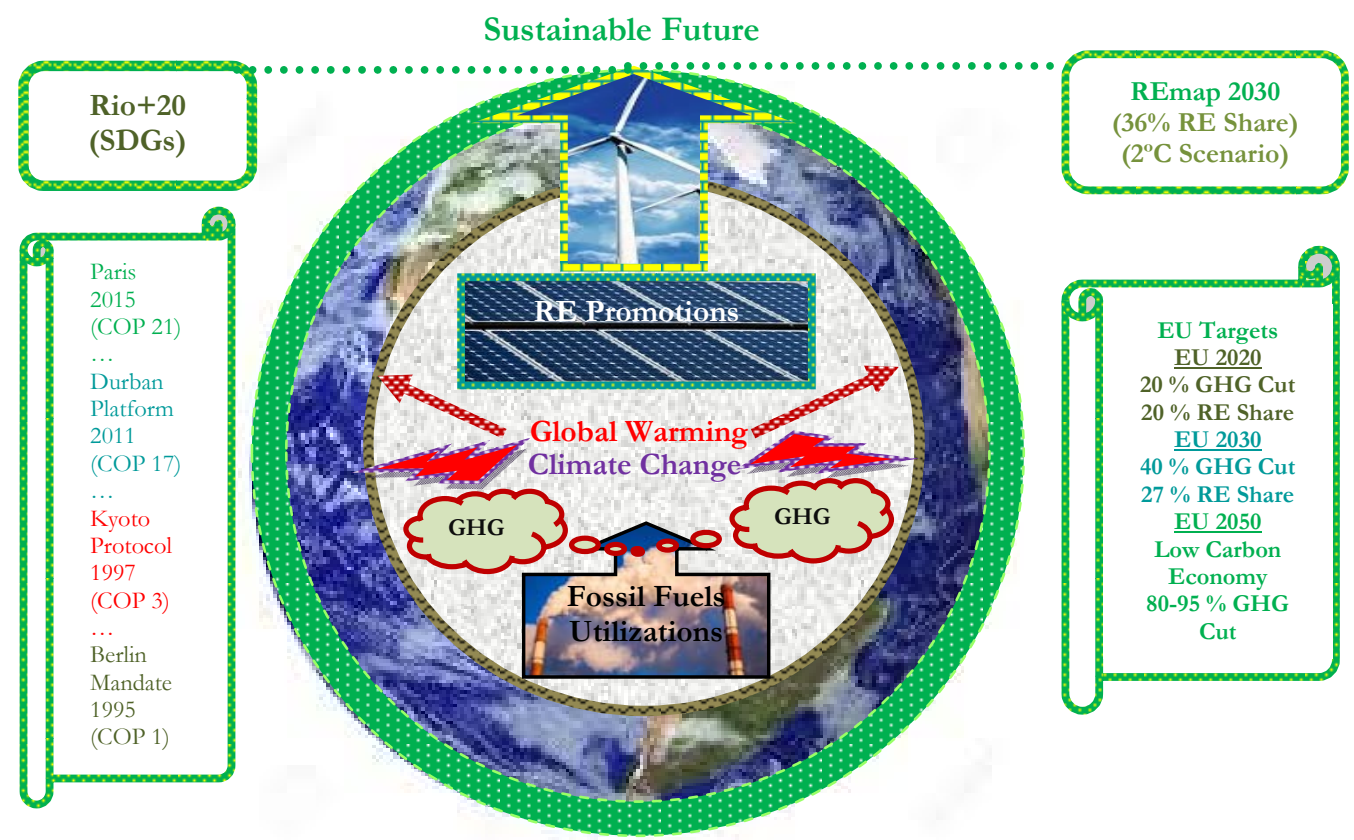

Fig.1 RE Role in Green Strategies towards Sustainable Future of Mother Earth

\subsection{GHG Emissions}

Energy use accounted for over two-thirds (72\%) of total annual GHG emissions. In 2012, electricity generation is responsible for the bulk of these emissions as $44 \%$, followed by manufacturing $(19 \%)$ and transport $(18 \%)$ as reflected in Fig. 2 [4].

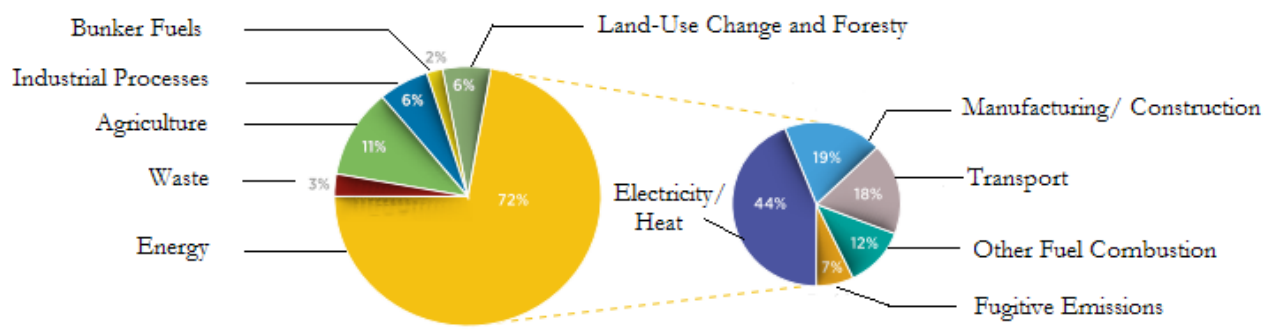

Source: World Resources Institute, 2015

Fig.2 GHG Emissions from Different Sectors in 2012

During 1990 to 2013, Global GHG emissions increased by 50\%. Fig.3 depicts the $\mathrm{CO}_{2}$ emissions from electricity generation have been continuously rising since 1990 , by $+2.7 \%$ /year on average, or $+79 \%$ over the whole period [3]. EU is responsible for around $9 \%$ of World GHG emissions [2]. At EU-28 level, emissions have decreased $12 \%$ since 1990 , reaching $1.1 \mathrm{GtCO}_{2}$ in 2011. French emissions were also down overall, but remained stable over the last three years. EU GHG emissions excluding Land Use, Land Use Change and Forestry (LULUCF) dropped by 19\% over the period 1990 to 2012. EU energy use was the main GHG emission source $(79 \%)$ and the highest GHG source was the energy sector (33\% of emissions), ahead of transport (20\%) [3]. 


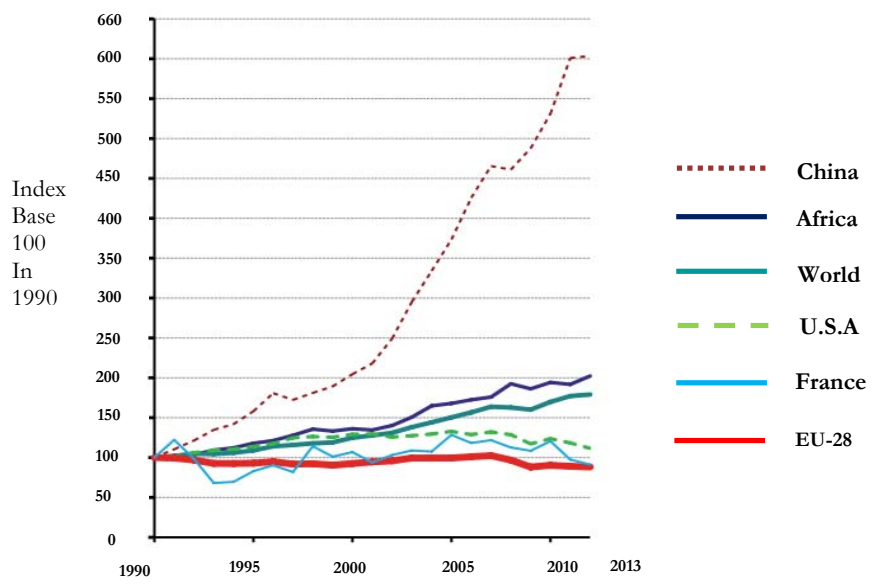

Source: IE A (As of September 2015)

Fig.3 GHG Emissions from 1990 to 2013

French GHG emissions were decreased by excluding LULUCF (11\%) over the period 1990 to 2013. Distribution of French GHG emissions (491.1 $\mathrm{MtCO}_{2}$ excluding LULUCF) by 2013 as illustrated in Fig.4. From it, energy use was the main GHG emission source in France (69.4\%) that including highest transport sector (28\%) and low emissions $(11 \%)$ of the electrical energy sector owing to the nuclear electricity generation [3]. The limited deployment of fossil fuel power plants causes French $\mathrm{CO}_{2}$ emissions in the electricity sector were effectively reduced by more than $40 \%$ in 2014, amounting to $19 \mathrm{MtCO}_{2}$ equivalent [5].

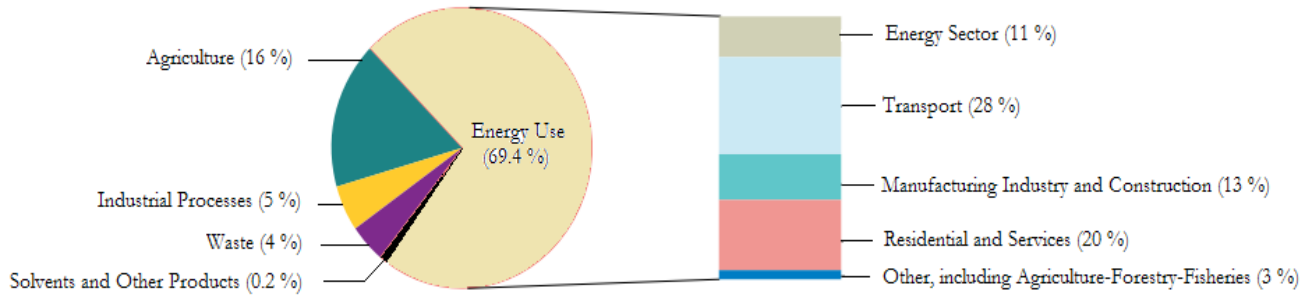

Source: CITEPA, inventory Climate Plan format (Kyoto scope) (As of April 2015)

Fig. 4 Distribution of French GHG emissions (as \%) in 2013

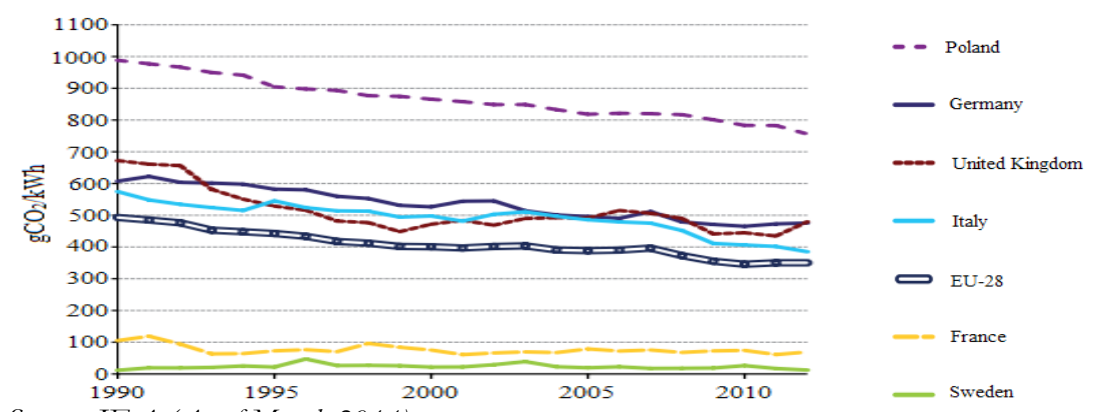

Source: IEA (As of March 2014)

Fig. $5 \mathrm{CO}_{2}$ emissions per kWh (unit) of Electricity Generation in EU 
Fig.5 reflects that $\mathrm{CO}_{2}$ emissions/kWh of electricity generation (including cogeneration) vary greatly from one country to another in EU-28. These are very high (over $400 \mathrm{gCO}_{2} / \mathrm{kWh}$ ) in countries where coal remains a major source, such as Germany and some countries in Central and Eastern Europe. $\mathrm{CO}_{2}$ emissions are low in countries where renewable energy and/or nuclear power have been developed, such as France (76\% nuclear and 10\% hydro) and Sweden (47\% hydro and 38\% nuclear) [3]. The atmospheric concentration of carbon dioxide $\left(\mathrm{CO}_{2}\right)$, is at its highest level for at least 800000 years. Even if GHG emissions are cut sharply, Climate Change will become more severe for decades to come because of the delayed effect of past emissions. Adapting to climate change has become an indispensable complement [2].

\subsection{Global Warming}

There is unequivocal evidence that the Earth's climate is warming. Each of the past three decades has been warmer than any preceding decade since records began in the year 1850 [2]. By the year 2012, the average global surface temperature was $0.85^{\circ} \mathrm{C}$ higher than in the year 1880, according to the UN Intergovernmental Panel on Climate Change (IPCC), which brings together thousands of the world's leading climate scientists. In the year 2014 , the average global surface temperature was $0.57 \pm 0.09^{\circ} \mathrm{C}$ higher than the norm calculated for the period 1961 to $1990\left(14^{\circ} \mathrm{C}\right)$. This was $0.08^{\circ} \mathrm{C}$ over the temperature average for the last ten years (2005-2014). It was the warmest year on record since 1880. Globally, the warmest years since 1880 have all occurred after the year 1998 as mentioned in Fig. 6 [3].

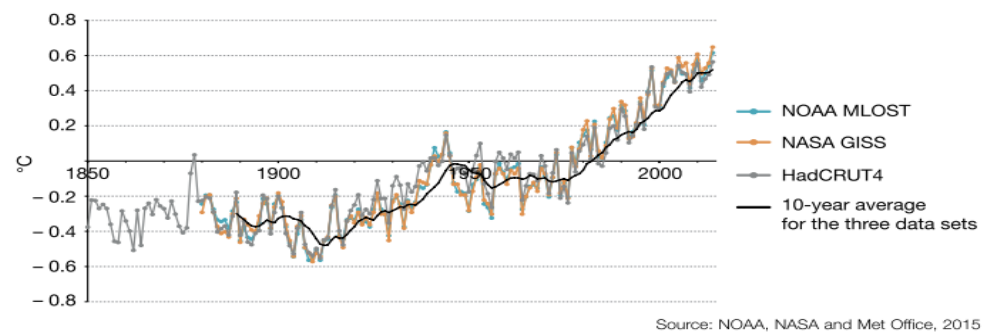

Fig.6 Global Average Temperatures from 1850 to 2014 compared to the Reference Period 1961-1990

In metropolitan France, the average increase in air temperature has been around $0.7^{\circ} \mathrm{C}$ over the whole $20^{\text {th }}$ century in north-eastern parts. The increase is more pronounced in the south-west where it has reached over $1.1^{\circ} \mathrm{C}$. As was the case worldwide, 2014 was the warmest year ever recorded in France, at $+1.9^{\circ} \mathrm{C}$ over the years 1961 to 1990 average, thus beating the previous record from the year 2011 $\left(+1.8^{\circ} \mathrm{C}\right)$ as shown in Fig. 7 [3].

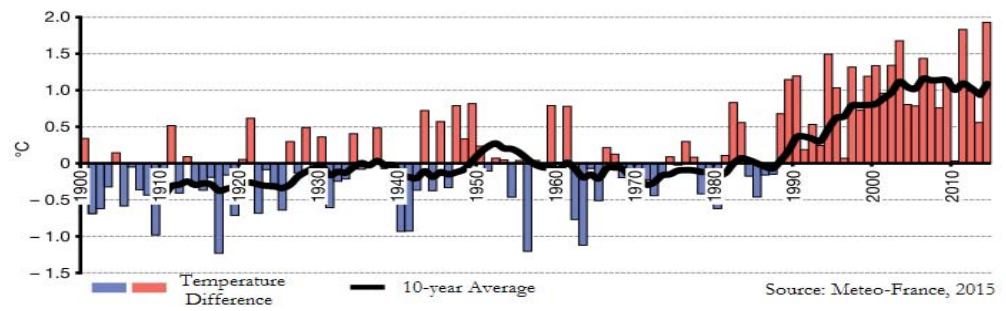

Fig.7 Average temperature change in France (1900-2014) compared to the Reference Period 1961-1990 
At Warsaw Conference (COP19), Governments were invited to submit a set of policy pledges, or Intended Nationally Determined Contributions (INDCs). Due to an analysis that carried out by Climate Action Tracker (2015), if all INDCs are fully implemented, there would still be an estimated increase in average global temperature rise of approximately $2.7^{\circ} \mathrm{C}$ up to the end of the century, 2100 as reported in Fig. 8 [4].

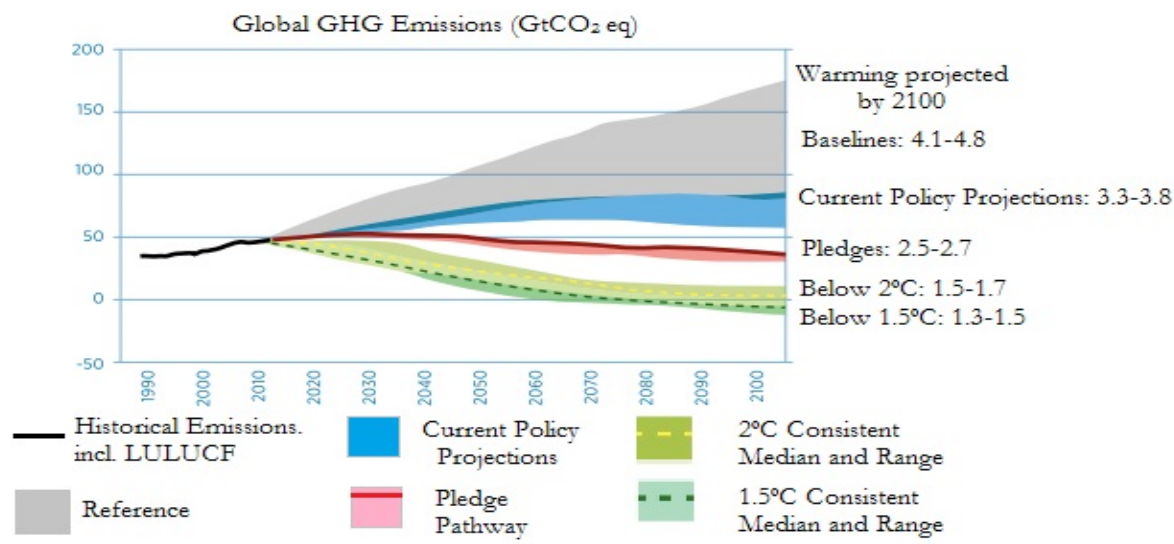

Source: Climate Action Tracker, 2015

Fig.8 Effect of Current Pledges and Policies on Global Temperature up to 2100

\subsection{Negative Impacts}

Human-made warming is causing discernible climatic and environmental changes, such as more frequent or severe extreme weather, rising sea levels, and the melting of glaciers and polar ice. The global average sea level rose by $1.7 \pm 0.3 \mathrm{~mm} / \mathrm{yr}$ over the period 1901-2010[3]. As highlighted in Fig.9, the rise has been greater in recent decades, reaching $3.2 \pm 0.4 \mathrm{~mm} /$ year over the period 1993-2010 (satellite data). Glacial reduction did not occur evenly throughout this period, with two phases of sharp decline: during the years 1942 to 1953 and from the year 1985 onwards. The sharp decline in the forties was primarily due to low snowfall in the winter and very hot summers. The significant loss of glacier mass recorded since 1982 is the result of very evident increase in summer melting. This mass loss has become more pronounced since 2003 as shown in Fig.10. The schematic map of potential impacts of climate change in metropolitan France by the year 2050 and beyond are demonstrated in Fig. 11 [3].

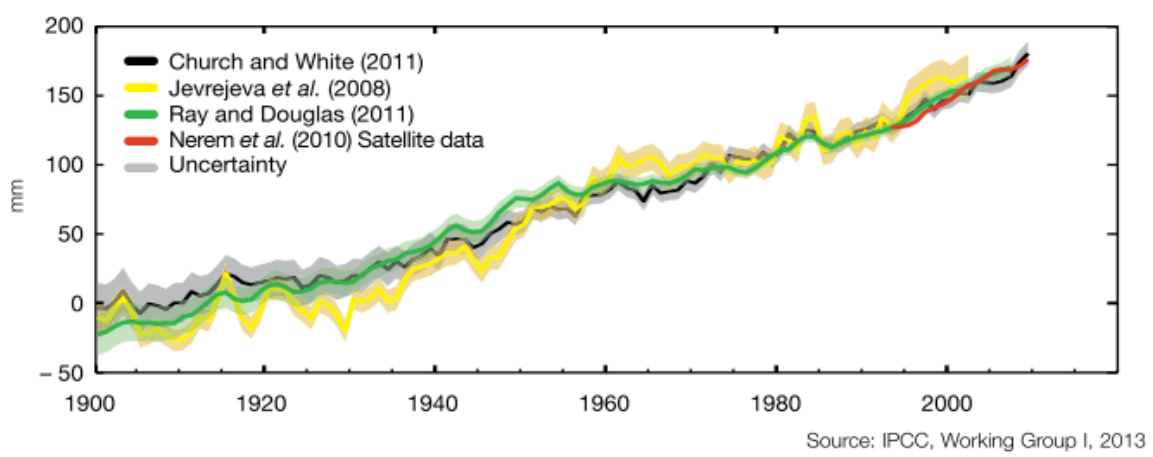

Fig.9 Global Average Sea Level Change compared to the Reference Period 1900-1905 


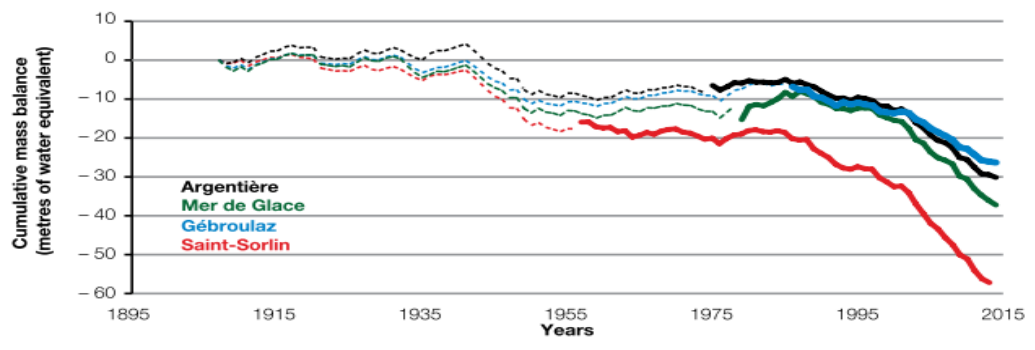

Note: Data for the $1^{\text {st }}$ half of the $20^{\text {th }}$ century (dotted line) were obtained from model simulations.

The solid lines are observations.

Fig.10 Change in Mass Balance of Temperate Glaciers in the French Alps since 1904

ALL REGIONS:

Warming more pronounced in summer and in the south-east quarter:

- Sharp increase in the number of days of heat wave in summer;

- Evaporation with reduced base flows and water resources for agriculture;

- Effects on crop yields.

- LARGE CITIES:

- More intense heat waves with consequences on health and energy consumption;

- Increased risk of urban flooding: overflow of sewerage systems, flooding of underground infrastructure.

FORESTS:

- Risk of forest fires extended towards the north.

MOUNTAINS:

- Reduced surface area of ski slopes;

- Increased natural hazards: debris flows in some mountain ranges;

- Biodiversity: changes in species. distribution

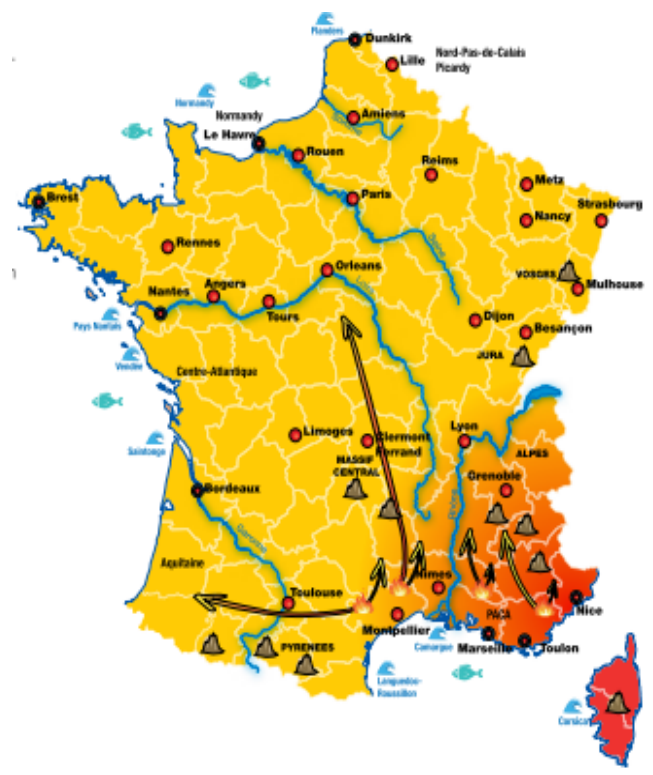

COASTLINES:

- Accentuated risk of erosion, submergence and salinisation of aquifers due to rising sea levels;

- More frequent risk of partial flooding of polders and barrier beaches;

- Ports and related industries at risk of coastal flooding;

- Changes in the distribution of fisheries resources with northward movement.

Sources: I4CE, 2015, due to IPCC (2014), MEDDE (2014- 2015), ONERC (2010) and Météo-France Fig.11 Schematic Map of the Potential Impacts of Climate Change in French Metropolitan by 2050 and Beyond

\section{Global Strategic Fight against Climate Change Challenge \\ 2.1 Emissions Savings by Boosting of Renewable Energy Role}

There is growing awareness that increased deployment of Renewable Energy and Energy Efficiency (RE and EE) are essential weapons for fighting the climate change challenge, creating new economic opportunities, and providing energy access to the billions of people still living without modern energy services. Harnessing of RE is evidently contributing to emissions reductions in the power sector. In 2012, $3.1 \mathrm{GtCO}_{2}$ equivalent of emissions was avoided through $\mathrm{RE}$ deployments, compared to the emissions from fossil fuel-based power generations [1]. 
Without RE generation, total emissions from the power sector would have been $20 \%$ higher [4]. Although these avoided emissions come primarily from hydropower, there is a spectacular increase of productions from other RE sources over the past decade.

\subsection{Global Investment Rise up in RE}

Global new investment in renewable power and fuels (not including hydropower larger than $50 \mathrm{MW}$ ) was up $17 \%$ over 2013, to US\$ 270.2 billion. Including the unreported investments in hydropower projects larger than $50 \mathrm{MW}$, total new investment in renewable power and fuels reached at least US\$ 301 billion [1]. It should reach US\$ 500 billion in 2020 [4]. PV modules in 2014 cost up to $80 \%$ less than at the end of 2009 , while wind turbine prices declined by almost a third over the same period (IRENA, 2015c). As RE technologies are market-ready and in most places economically competitive with conventional energy sources, governments have initiated far-reaching structural changes in the energy market, scaling up the deployment of RE [7].

\section{A. Solar PV: Rapid Spread to New Markets}

Solar PV is starting to play a substantial role in electricity generation in some countries. The price of solar panels has come down. It was the intention behind government initiatives to provide financial support to buyers of PV. Those rapidly falling costs have made unsubsidised PV electricity cost-competitive with fossil fuels. In 2014, 40 GW PV installed for global capacity of 177 GW [1]. Prices for panel modules have dropped from US\$ 100/watt peak (Wp) in 1975 to below US\$ 0.60/Wp in 2014. Total system prices had fallen, dropping 15 to 23\%/year between 2010 and 2013. Depending on application and region, PV system cost at the end of 2013 is between US $\$ 1.29 / \mathrm{Wp}$ for a utility ground-mounted system and US\$2.00/Wp for EU residential rooftop system. The balance of system (BOS), including installation, is $50 \%$ of total system costs. Solar PV penetration rates will be high around the world. Fig.12 demonstrates that these rates vary substantially depending on the assumptions made. In its oceans scenario, Shell is the most optimistic with a penetration rate of more than $25 \%$ worldwide [6].

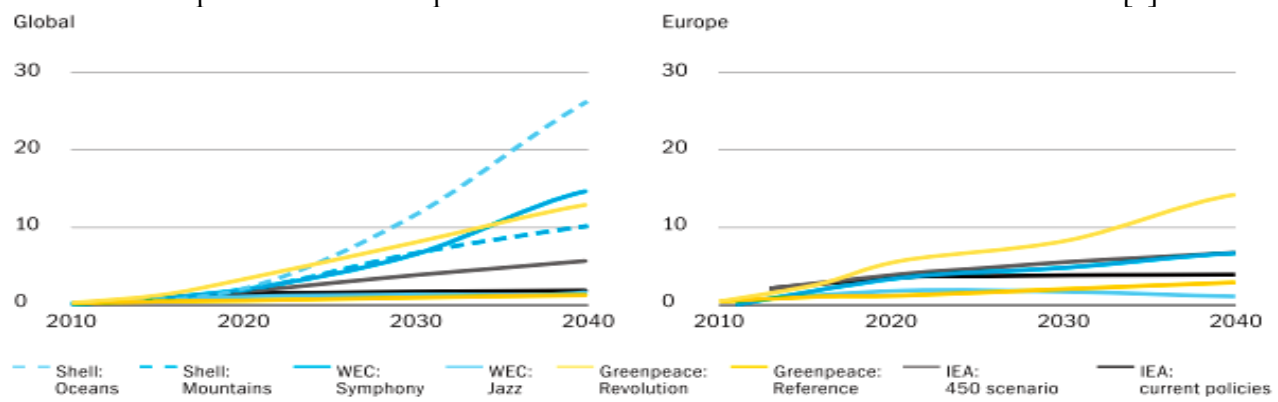

Source: IEA, European Commission DG TREN, Shell, WWF, Greenpeace, WEC, Roland Berger

Fig.12 Share of Solar PV in Total Electricity Generation by Energy Scenario (As TWh\%)

\section{B. Wind Power: The Cheapest Option for New Power Generation}

The global wind power market resumed its advance in 2014, adding a record 51 GW - the most of any renewable technology - for a year-end total of $370 \mathrm{GW}$. An estimated 1.7 GW of grid-connected capacity was added offshore for a world total exceeding 8.5 GW [1]. 


\subsection{REmap 2030}

A further reduction in absolute emissions will require a substantial decrease of emissions intensity in generation. The average emissions intensity has barely changed over the past 20 years as shown in Fig. 13. Under current policies and national plans, it is expected to fall from 575 grams per kilowatt hour $(\mathrm{g} / \mathrm{kWh})$ in 2010 to 488 $\mathrm{g} / \mathrm{kWh}$ by 2030. A further reduction of the emissions intensity to $362 \mathrm{~g} / \mathrm{kWh}$ that equivalent to a $40 \%$ intensity reduction from 1990 levels could be achieved by scaling-up $\mathrm{RE}$ deployment. Ramping up renewables is essential to meet climate goals without decelerating economic growth and reducing welfare [4]. Doubling RE share in total final energy consumption (TFEC) from $18 \%$ in 2010 to $36 \%$ by 2030 , combined with significant improvements in end-use (heating/cooling and transport) energy efficiency, is required to limit global temperature increases to under $2^{\circ} \mathrm{C}[9]$.

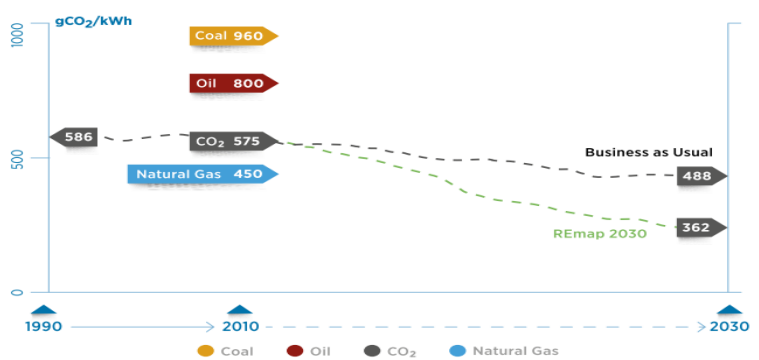

Source: IEA, 2010 and IRENA, 2014 b

Fig.13. Carbon-Dioxide Emissions Intensity of RE map 2030 Power Generation

As mentioned in Fig. 14, under business-as-usual (Reference Case), current policies and those under consideration will increase the renewables share of TFEC to only $21 \%$ by 2030 . In this case, annual global energy-related $\mathrm{CO}_{2}$ emissions will actually increase from $30.3 \mathrm{Gt} /$ year in 2010 to about $41.4 \mathrm{Gt} /$ year by 2030 . The gap between the Reference Case and the REmap 2030 options (36\%) corresponds to a reduction of 8.6 Gt of energy-related $\mathrm{CO}_{2}$ emissions per year by 2030 , due to avoided combustion of fossil fuels (of which 64\% would have been coal, $20 \%$ oil and 16\% natural gas) [9].

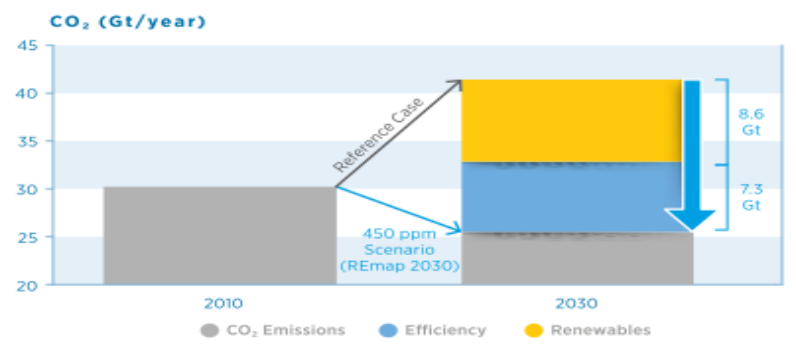

Source: IRENA, 2014 a

Fig.14. Saving Carbon-Dioxide Emissions under REmap 2030 (IRENA, 2014)

\subsection{Sustainable Development Goals (SDGs) and RE}

The concept of the SDGs was born at the Mega Summit Rio+20, United Nations Conference on Sustainable Development (UNCSD) that was successfully held in Brazil [40]. The core aim of that Earth Summit 2012 was to address a set of universally applicable Goals for good balancing the three dimensions of Sustainable 
Development: Environmental, Social, and Economic. SDGs replace the Millennium Development Goals (MDGs), which in September 2000 rallied the world around a common 15-year agenda to tackle the indignity of poverty. To turn the World demands into actions, the world leaders adopted the 2030 Agenda for Sustainable Development on 25 September 2015 in New York. The 2030 Agenda comprises 17 new Sustainable Development Goals (SDGs) that will guide Green Policy and funding for the next 15 years, beginning with a historic pledge to end poverty. SDG 7 urges policy makers to ensure access to affordable, reliable, sustainable, and modern energy for all. SDG 7 is not only goal that explicitly addresses the energy sector and mentions RE as a mean to achieve it but also crucial to gain the other SDGs. This is particularly the case for sustainable industrialization, fostering innovation (SDG 9), reduction of inequalities (SDG 10), ending poverty (SDG I), and sustainable economic growth (SDG 8). The nexuses between RE and SDGs are highlighted in Fig. 15 [4].

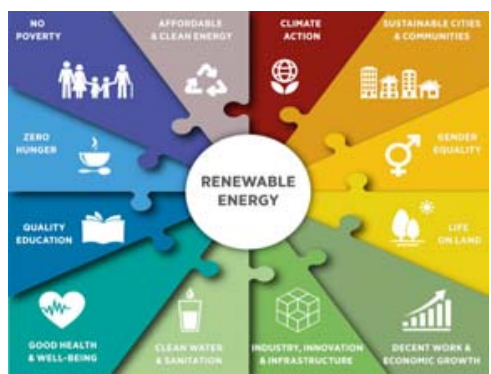

Fig.15 Nexuses between RE and SDGs

Governments are intending to gain Goal 7 by increasing substantially share of $\mathrm{RE}$ in Global Energy Mix as well as doubling the Global rate of improvement in EE (Energy Efficiency) [7]. Targets of Gold 7 are reported as the following [8]:

- 7.1 By 2030, ensure universal access to affordable, reliable and modern energy services;

- 7.2 By 2030, increase substantially the share of RE in the global energy mix;

- 7.3 By 2030, double the global rate of improvement in EE;

- 7.a By 2030, enhance international cooperation to facilitate access to clean energy research and technology, including RE, EE and advanced and cleaner fossil-fuel technology, and promote investment in energy infrastructure and clean energy technology;

- 7.b By 2030, expand infrastructure and upgrade technology for supplying modern and sustainable energy services for all in developing countries, in particular least developed countries, small island developing States, and landlocked developing countries, in accordance with their respective programmes of support.

\subsection{Paris Climate Agreement (2015)-COP21}

After over 20 years of U.N. negotiations, the world rightly celebrated when 195 countries including EU signed onto a first step of historic global agreement on climate change at COP (Conference of the Parties) 21 in Paris on 12 December 2015. This 
event is a critical turning point, a fundamental pivot towards a zero-carbon and climateresilient world and launched for signature in New York, until 17 April 2017 Countries will also need to adopt the agreement within their own legal systems, through ratification, acceptance, approval or accession. The timeline for signature and ratification for three examples of Paris Agreement are shown in Figs. 16 and 17 [10]. The agreement will enter into force when joined by at least 55 countries, which together represent at least $55 \%$ of global emissions. China, U.S. and as many as 155 other countries signed the Paris Climate Agreement (2015) at an historic global ceremony at the United Nations' headquarters in New York on April 22, 2016 [11]. On this International Mother Earth Day, France and India leaded for the agreement on US\$ 1000 billion Solar Alliance with 25 countries to accelerate massive PV deployment, upgrade the PV R\&D collaboration and uplift the integration on Solar PV Energy [37, 41].

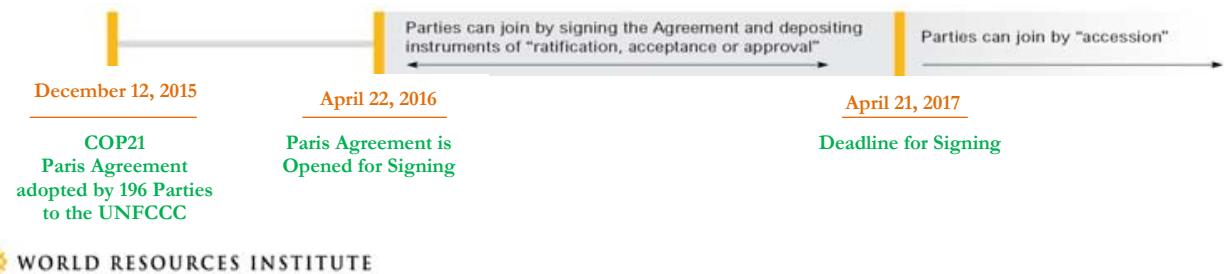

Fig.16 Timeline for Signature and Ratification of the Paris Agreement
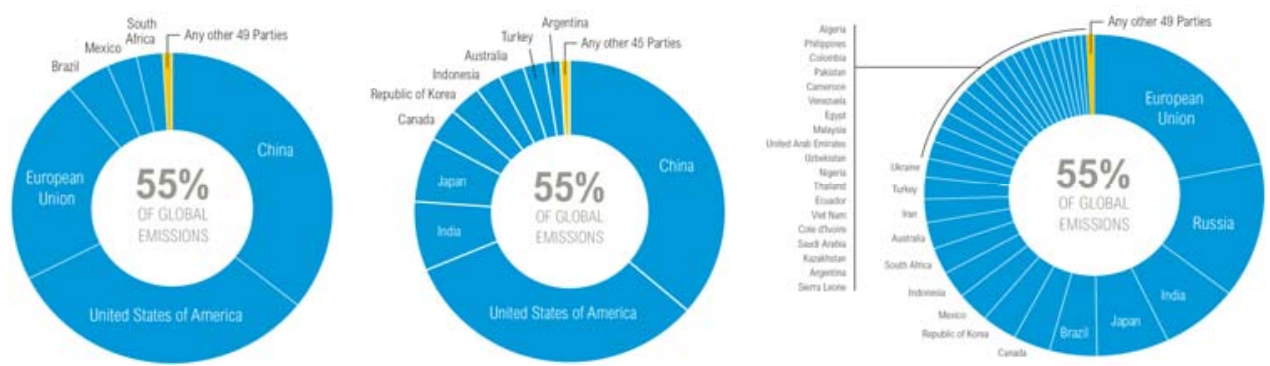

WORLD RESOURCES INSTITUTE

Fig.17 Three Examples of How the Paris Agreement Could Take Place

\section{EU Green Strategies against Climate Change Challenge}

\subsection{EU 2020 Climate and Energy Package}

EU 2020 package is a set of binding legislation to ensure EU meets its climate and energy targets for 2020. These are headline targets of EU strategy for smart, sustainable and inclusive growth. The package sets three key targets as follows [12]:

- $20 \%$ cut in GHG emissions (from 1990 levels);

- $20 \%$ of EU energy from RE;

- $20 \%$ improvement in EE.

The targets were set by EU leaders in 2007 and enacted in legislation in 2009. As informed in [13], 20\% energy savings (or EE) target by 2020 when compared to the projected use of energy in 2020 is roughly equivalent to turning off 400 power stations. 


\subsection{EU Rules and Guidelines for 2020 Climate Targets}

As indicated in [14], EU has adopted new rules and guidelines on public support for Member States' projects in the field of environmental protection and energy to meet 2020 targets. These are valid from 1 July 2014. Key features are summarized as gradual introduction of market based mechanisms; promoting competitiveness of European industry; supporting cross-border energy infrastructure to further the Single European Energy Market; and permitting the aid to secure adequate electricity generation.

\subsection{EU 2030 Energy Strategy}

At an EU summit on October 2014, EU countries have agreed on a new 2030 Framework for climate and energy. Targets for EU 2030 Energy Strategy are [15]:

- $\quad 40 \%$ cut in GHG emissions compared to 1990 levels;

- $\quad$ at least a $27 \%$ share of RE consumption;

- at least $27 \%$ energy savings compared with the business-as-usual scenario The EU 2030 Policies has proposed to meet these targets:

- Reform ETS;

- New indicators for the competitiveness and security of the energy system, such as price differences with major trading partners, diversification of supply, and interconnection capacity between EU countries;

- First ideas on new governance system based on national plans for competitive, secure and sustainable energy. These plans will follow a common EU approach. They will ensure stronger investor certainty, greater transparency, enhanced policy coherence and improved coordination across EU.

Moreover, EU had proposed 30\% in its EE Communication. In line with the request of the European Council, this quantifies the contribution that EE could cause GHG emissions reductions and to improve EU energy security which are both facets of an integrated framework for climate and energy policy.

The EU has adopted a number of measures to improve Energy Efficiency (EE):

- an annual reduction of $1.5 \%$ in national energy sales;

- EU countries making energy efficient renovations to at least $3 \%$ of buildings owned and occupied by central governments per year;

- mandatory EE certificates accompanying the sale and rental of buildings;

- minimum EE standards and labelling for a variety of products such as boilers, household appliances, lighting and televisions (EcoDesign);

- the preparation of National EE Action Plans every three years by EU countries;

- the planned rollout of close to 200 million smart meters for electricity and 45 million for gas by 2020 ;

- large companies conducting energy audits at least every four years;

- protecting the rights of consumers to receive easy and free access to data on real-time and historical energy consumption [35].

Fig. 18 depicts EU's transport emissions reduction scenario by 2030. The $130 \mathrm{~g} / \mathrm{km}$ target for 2015 has already overachieved across the new car fleet as a whole. On average the $95 \mathrm{~g} / \mathrm{km}$ target is expected to be met by 2021 but this masks widely differing performances between carmakers. The required non-ETS (principally 
building, agriculture and transport) emissions reduction is 936 Megatonnes of $\mathrm{CO}_{2}$ Equivalent (Mt) from 2005 to 2030. Realistically transport will need to be making a sizable contribution to achieving this reduction, 20 to $40 \%$ reduction in the sector contributing 174 to $364 \mathrm{Mt}$ [16]. Analysis of T\&E (European Federation for Transport and Environment) shows 2025 and $2030 \mathrm{CO}_{2}$ standards for cars, vans trucks and buses can contribute a sizable $110 \mathrm{Mt}$ to the required emissions reductions [17].
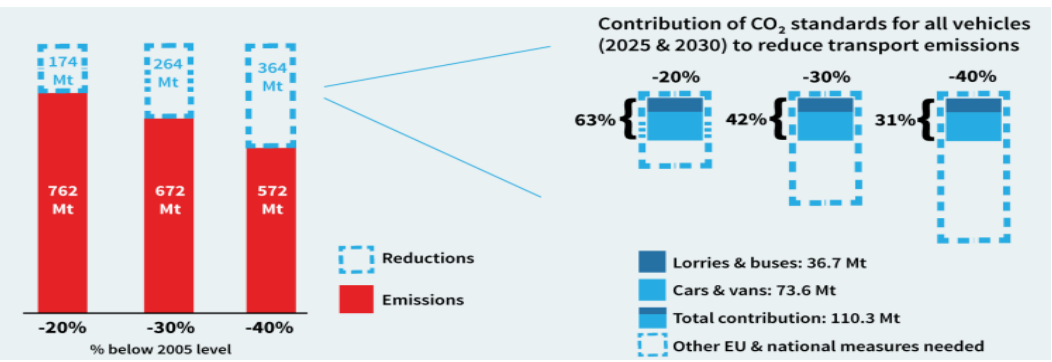

Source: T\&̈Ein-house analysis,

Fig.18 EU Transport Emissions Reduction Scenario by 2030

\subsection{EU 2050 Low-Carbon Targets}

EU is looking at cost-efficient ways to make European economy more climatefriendly and less energy-consuming. Its low-carbon economy roadmap addresses [18]:

- By 2050, the EU should cut emissions to 80\%(to 95\%) below 1990 levels;

- Milestones to achieve this are $40 \%$ emissions cuts by 2030 and $60 \%$ by 2040 ;

- All sectors need to contribute;

- The low-carbon transition is feasible and affordable.

All sectors need to contribute to the low-carbon transition according to their technological and economic potential. Action in all main sectors responsible for EU emissions (power generation, industry, transport, buildings, construction and agriculture) will be needed, but differences exist between sectors on the amount of reductions that can be expected (Fig. 19).

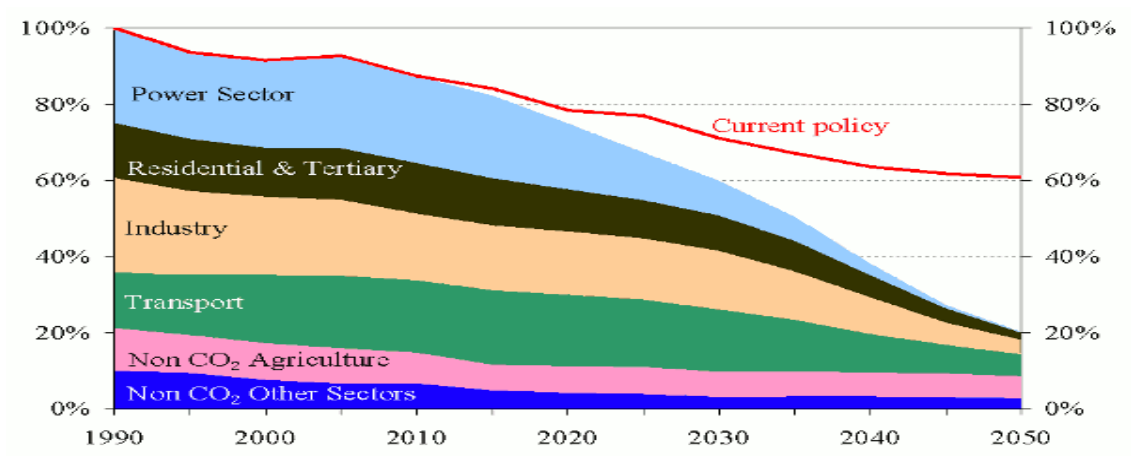

Source: EU 2050 Low-Carbon Economy

Fig.19 EU Emissions Cut by Sectors 


\section{French Green Strategies against Climate Change Challenge \\ 4.1 Renewable Energy Feed-in-Tariffs (I)}

The following feed-in tariffs listed in Table 1 were established under the Electricity Law of 2000. All sites benefiting from the mandatory buyback rates must be under $12 \mathrm{MW}$ of nominal capacity. FIT for most technologies have been superseded by subsequent regulations, except for biogas from landfills, municipal solid waste and cogeneration. Tariffs for landfill biogas and municipal solid waste run 15 years, while those for cogeneration are 12 years [19].

\section{Table1. List of French FIT (I) Rates}

\begin{tabular}{|c|c|}
\hline RE Type & FIT (I) Rate \\
\hline Wind energy & $\begin{array}{l}\text { Production sites built after the law was published (November 2001) can sign a } 15 \text { years contract } \\
\text { which guarantees a FF (French franc) } 0.55 / \mathrm{kWh}(0.0838 \text { ) rate for the first } 5 \text { years for all sites. } \\
\text { The tariff for the next } 10 \text { years depends on wind conditions; plants working at full capacity for } \\
\text { less than } 2,000 \text { hours continue to get } € 0.0838 \text {, those at a full-capacity of } 3,600 \mathrm{~h} / \text { year receive } \\
0.0541 / \mathrm{kWh} \text { (tariffs in between are determined by a linear regression). These tariffs apply for the } \\
\text { first } 1,500 \mathrm{MW} \text { of nationally installed capacity, thereafter all tariffs decrease by } 10 \% \text { (only for } \\
\text { new projects). These tariffs are applicable until December } 2002 \text {, after they decrease by } 3.3 \% \\
\text { annually to reflect technology learning. }\end{array}$ \\
\hline Small hydro & $\begin{array}{l}\text { Production sites built after the publication of the law (or for the marginal production from } \\
\text { retrofits increasing production by more than } 10 \% \text { ) can sign a twenty-year contract which } \\
\text { guarantees FF } 0.40 / \mathrm{kWh}(0.0610) \text { for sites with a capacity under } 500 \mathrm{~kW} \text { and FF } 0.36 / \mathrm{kWh} \\
(0.0549) \text { for larger ones. An incentive for regularity of production of up to FF } 0.10 / \mathrm{kWh} \\
\text { (0.0152) is available in winter (regularity and winter incentives can be separated). }\end{array}$ \\
\hline $\begin{array}{l}\text { Combustible } \\
\text { Waste }\end{array}$ & $\begin{array}{l}\text { Production sites built after the publication of the law are guaranteed rates of up to FF } \\
0.299 / \mathrm{kWh}(0.0456) \text { for medium-voltage connections and FF } 0.274 / \mathrm{kWh}(0.0418) \text { for high- } \\
\text { voltage connections. }\end{array}$ \\
\hline $\begin{array}{l}\text { Solar (PV or any } \\
\text { Radiative } \\
\text { Technology) }\end{array}$ & $\begin{array}{l}\text { The rate is } 0.305 / \mathrm{kWh} \text { in the overseas departments and Corsica, and } 0.0155 / \mathrm{kWh} \text { on mainland } \\
\text { France. It also provides a grant of } 4.6 / \text { watt for direct grid-connected installations. }\end{array}$ \\
\hline $\begin{array}{l}\text { Biogas from } \\
\text { Landfills }\end{array}$ & $\begin{array}{l}\text { Production sites built after the publication of the law are guaranteed, in metropolitan France, } \\
\text { rates up to } 0.0572 / \mathrm{kWh} \text { for small installations, up to } 0.0450 / \mathrm{kWh} \text { for large installations and } \\
\text { linear interpolation for medium-sized installations. }\end{array}$ \\
\hline $\begin{array}{l}\text { Municipal solid } \\
\text { waste (other } \\
\text { than biogas) }\end{array}$ & $\begin{array}{l}\text { Rate of } € 0.045 \text { to } € 0.05 / \mathrm{kWh} \text { with a bonus for energy efficiency ranging from } 0 \text { to } € \\
0.003 / \mathrm{kWh} \text {. }\end{array}$ \\
\hline Cogeneration & Rate of $€ 0.061$ to $€ 0.0915 / \mathrm{kWh}$, according to the price of gas, running time and power. \\
\hline
\end{tabular}

\subsection{Renewable Energy Feed-in-Tariffs (II)}

In 2002, feed-in tariffs were set for the following renewable energy sources, completing the list of tariffs provided for in the Electricity Law, which came into force in 2001. These tariffs have been set for 15 years, except for solar PV which is for 20 years as listed in Table 2 . All sites benefiting from the mandatory buyback rates must be under 12 MW of nominal capacity [19].

\section{Table 2 List of French FIT (II) Rates}

\begin{tabular}{|l|l|l|}
\hline RE Type & Decree Date & FIT (II) Rate \\
\hline Biomass & 16 April 2002 & $€ 0.049 / \mathrm{kWh}$, plus bonus for efficiency of between 0 and $€ 0.12 / \mathrm{kWh}$ \\
\hline Methanisation & 16 April 2002 & $€ 0.046 / \mathrm{kWh}$, plus bonus for efficiency of between 0 and $€ 0.12 / \mathrm{kWh}$ \\
\hline Geothermal & 13 March 2002 & $€ 0.0762 / \mathrm{kWh}$, with a bonus for efficiency between 0 and $€ 0.003 / \mathrm{kWh}$ \\
\hline Animal waste & 13 March 2002 & $\begin{array}{l}€ 0.045 \text { to EUR } 0.05 / \mathrm{kWh} \text {, with a bonus for efficiency between } 0 \text { and } € \\
0.003 / \mathrm{kWh}\end{array}$ \\
\hline Solar PV & 13 March 2002 & $\begin{array}{l}€ 0.305 / \mathrm{kWh} \text { has been set in the overseas departments }(\mathrm{DOM}), \text { in the } \\
\text { islands of Saint Pierre of Miquelon and Corsica and of } € 0.152 / \mathrm{kWh} \text { for } \\
\text { mainland France. }\end{array}$ \\
\hline
\end{tabular}




\subsection{Renewable Energy Feed-in-Tariffs (III)}

French FIT (III) Rates are mentioned in Table 3. These has been effective since 2006 with Fiscal/financial incentives and Feed-in tariffs/premiums. Under the Electricity Law 2000, it was introduced on 10 July 2005. These apply for contracts of 15 years (except for Offshore Wind and PV, for which they apply to contracts of 20 years) [19]:

\section{Table 3 List of French FIT (III) Rates}

\begin{tabular}{|l|l|}
\hline $\begin{array}{l}\text { RE Type } \\
\text { Methanisation }\end{array}$ & $\begin{array}{l}\text { Between } 7.5 \text { and } 9 € \text { cents } / \mathrm{kWh} \text {, with an energy efficiency bonus of between } 0 \text { and } 3 € \text { cents } \\
\text { and a methanisation bonus of } 2 € \text { cents } / \mathrm{kWh}\end{array}$ \\
\hline Onshore Wind & $€ 0.046 / \mathrm{kWh}$, plus bonus for efficiency of between 0 and $€ 0.12 / \mathrm{kWh}$ \\
\hline Offshore Wind & $\begin{array}{l}\text { (Contracts for } 20 \text { years): } 13 € \text { cents } / \mathrm{kWh} \text { for } 10 \text { years, then a variable rate for the next } 5-10 \text { years } \\
\text { ranging from } 3 € \text { cents } / \mathrm{kWh} \text { for a plant operating } 3900 \text { hours or more to } 13 € \text { cents } / \mathrm{kWh} \text { for } \\
2800 \text { hours or less. Rates fall by } 2 \% \text { a year for plants built after } 1 \text { January } 2008 \text {, while also } \\
\text { adjusted to take account of inflation. Annulled in August } 2006 \text {, the tariff for wind power was } \\
\text { reinstated mid-December. }\end{array}$ \\
\hline Solar PV & $\begin{array}{l}30 € \text { cents } / \mathrm{kWh} \text {, with a construction bonus of } 25 € \text { cents } / \mathrm{kWh} \text { for mainland France and } 40 € \\
\text { cents } / \mathrm{kWh}, \text { with construction bonus of } 15 € \text { cents in the outer French territories }\end{array}$ \\
\hline Geothermal & $\begin{array}{l}12 € \text { cents } / \mathrm{kWh} \text { with an energy efficiency bonus of between } 0 \text { and } 3 € \text { cents for mainland } \\
\text { France and } 10 € \text { cents } / \mathrm{kWh} \text {, with an energy efficiency bonus of between } 0 \text { and } 3 € \text { cents on } \\
\text { Corsica }\end{array}$ \\
\hline
\end{tabular}

\subsection{Renewable Energy Feed-in-Tariff: Solar PV (Photovoltaic)}

It superseded PV of FITs (III). It has been effective in 2010 and amended in 2011. In March 2011, France adjusted it and structured along two main systems:

- FIT is adjusted every trimester for building installation no bigger than $100 \mathrm{~kW}$;

- Tenders for building installations larger than $100 \mathrm{~kW}$ and ground mounted plants.

When PV installed capacity reaches or exceeds the fixed cap of $100 \mathrm{MW} / \mathrm{year}$ for residential and $100 \mathrm{MW} /$ year for non residential caps, tariffs will drop by $2.6 \%$ each trimester, $10 \%$ annually and less so if the installation rate slows down. Tariffs by 2006 will continue to apply to certain kinds of projects submitted in late 2009, before 11 January 2010, and certain small- and medium-sized projects in agricultural sector [19].

As of March 2011:

- Building-integrated photovoltaic installations (BIPV) no larger than $9 \mathrm{kWc}$ are entitled $€ 0.46 / \mathrm{kWh}$, and installation between $9-36 \mathrm{kWc}$ is $€ 0.40 / \mathrm{kWc}$.

- Simplified BIPV systems: $€ 0.30 / \mathrm{kWh}$ for plants no larger than $36 \mathrm{kWc}$ and $€ 0.29 / \mathrm{kWc}$ for plants between 36 and $100 \mathrm{kWc}$; the system must be safely installed parallel to the roof, and fulfill cover and staunchness requirements.

\section{As of 2010:}

- Ground-mounted solar arrays: Benefit from a base tariff of $€$ cent $31.4 / \mathrm{kWh}$. For systems greater than $250 \mathrm{kWc}$, the tariff varies according to a regional coefficient ranging from 1 to 1.2, offering higher tariffs for less sunny regions. In Corsica and overseas regions, the tariff is $€$ cent $40 / \mathrm{kWh}$ [19].

\subsection{NREAP (National Renewable Energy Action Plan)}

NREAP has been effective since 2010. Under the EU Directive 2009/28/EC member countries are obliged to draft and submit to the European Commission NREAPs (National Renewable Energy Action Plans) outlining pathway which will allow them to meet their 2020 RE, EE (Energy Efficiency) and GHG cuts targets [19]. 
The French 2020 REAP targets are mentioned as follows:

- Overall target: $23 \%$ of share of energy generated from RE sources in gross final energy consumption;

- Heating and cooling: 33\% of heat consumption met by RE sources;

- Electricity: $27 \%$ of electricity demand met by generation from RE sources;

- Transport: $10.5 \%$ of energy demand met by RE sources.

France runs incentives such as modifications of administrative procedures in order to achieve 2020 targets and overcome administrative barriers of RE deployment, tax reliefs, measures improving EE and Energy Savings in buildings, grants, financial aid to RD\&D (Research, Development and Deployment) of RE and EE technologies, and Investments in railway infrastructure with purpose of Energy Savings [19].

\subsection{Green Innovation Funding: French Programme of investments for Future}

This French jurisdiction is categorized with RD\&D. It is targeted for Multiple RE sources and it is Multi-sectoral Policy. Since 2010, Agency for the Environment and Energy Management (ADEME) has been in charge of four investment programmes to support testing in real conditions and demonstration plants (projects) for RE and green chemistry ( $€ 1.1$ billion), Smart Grid (€ 165 million), circular economy (€ 210 million) and Low-carbon vehicles ( $€ 950$ million). Totaling $€ 2.45$ billion of credits, this initiative is part of the $€ 35$ billion investments for the Future (PIA) programme. It is demonstrating its ability to unite companies and research partners, and to stimulate their innovation capabilities. Compared to other national research programmes, this aims at bringing innovation to the market and focuses on specific fields set up by strategic roadmaps. To manage these projects, ADEME developed specific financial tools, bearing in mind the public objectives of job creation, activity development in the French territory, economic competitiveness and environmental benefits [19].

\subsection{Energy Transition Act}

It is related with the NREAP and effective in July, 2015. In mid-2014 France has revealed a draft of its Energy Bill (likely to be adopted in 2015) establishing climate and RE targets to be reached by 2030. The split of RE target for 2030 that followed from NREAP model is addressed:

- Overall target: 32\% share of RE generation in gross final energy consumption;

- Heating and cooling: 38\% share of heat consumption met by RE sources;

- Electricity: $40 \%$ of electricity demand met by generation from RE sources;

- Transport: $15 \%$ of energy demand met by RE sources.

In order to reach the above 2030 target France is planning to use mechanisms set by NREAP. The Bill set a goal to cut GHG emissions by 40\% (compared to 1990 baseline) and to reduce overall fossil fuel consumption $30 \%$ by 2030 . Also France is aiming at decreasing its reliance on nuclear energy power generation. The goal is to reduce the share of nuclear energy to $50 \%$ of electricity production by 2025 , from around $75 \%$ in 2014 [19]. 


\subsection{French National Low-Carbon Strategy}

French national low-carbon strategy (SNBC), established by the Energy Transition Act, defines how to reduce GHG emissions at the national level. It orchestrates the implementation of the transition towards a low-carbon economy. On November 18, 2015, the French Government has adopted the first three carbon budgets to cover the 2015-2018, 2019-2023 and 2024-2028 periods. Two major goals of that Strategy are: to make the reduction of the carbon footprint a key consideration in economic decisions and to redirect investments in support of energy transition [19].

\section{French Icons of Green Growth and RE Statistics \\ 5.1 Lyon Smart Community}

In December 2012, Grand Lyon and NEDO are drawing up an initial assessment of the memorandum of agreement that signed on December 15, 2011, to turn the Confluence district in Lyon into a demonstration for a "Smart Community", the first of its kind in Europe. Detailed specification of partner roles were identified with the support of ADEME. NEDO (New Energy and Industrial Technology Development Organization) is the Japanese public body to support New Innovation under the aegis of Japanese Ministry of Economy, Trade and Industry (METI). NEDO will support $€ 50$ million in this NEDO's first Smart Community demonstration in Europe. It covers a total area of 150 hectares in the very heart of Lyon, where the rivers Rhone and Saone meet. It is poised to become one of Europe's flagship sustainable districts. It has won coveted Concerto status, been named as the first ever sustainable neighbourhood by WWF in 2010, and acclaimed as an eco-district by the French Ministry for the Ecology and Sustainable Development. Its four central aims are: embarking on the first stage of the process to achieve a positive-energy eco-district; reducing congestion and achieving carbon-free city travel; helping users control their energy use; and Managing data collection, aggregation and analysis. Four pillars of the demonstration that set up from 2012 to 2016 are: positive-energy buildings start to take shape; sustainable mobility - a car-sharing scheme with a fleet of electric vehicles; residential energy monitoring system - at the heart of environmentally responsible renovation; and community energy management system: facilitating the district's overall energy management [20].

\subsection{Neoen's 300 MW Europe's Largest Solar Park at Cestas}

Neoen, a major French renewable energy company, announces the completion of the development of Europe's largest Solar PV energy park, the completion of its related financing and start of construction works. It is located in Cestas, near Bordeaux, consists in several power plants with a total combined output of $300 \mathrm{MW}$. Neoen will own $120 \mathrm{MW}$ while eight other reputable investors will own the remaining $180 \mathrm{MW}$. Total investment for the project will exceed $€ 360$ million. It was connected directly to very high voltage grid and operated in October 2015 [21]. Electricity costs delivered by the plant are calculated to be $€ 105 / \mathrm{MWh}$ ( $\$ 131 / \mathrm{MWh}$ ) over 20 years [22]. It is covering 620 acres (250 hectares), will produce over $350 \mathrm{GWh} /$ year, about the neighboring town of Bordeaux requires. It is equivalent to one-third of a nuclear power plant, and nearly three times as much power as French next largest solar plant. The combination of lots of 
southern French sun, reasonably available tracts of land, and solar panels allow purchasers to enter contracts at $10.5 €$ cents/kWh [23].

\subsection{Nice Smart PV Grid Project}

The Nice Grid project in France brings together a broad range of stakeholders in the country's first smart solar-energy district demonstration project, and features integrated 1.5 MWh energy storage based on Saft's lithium-ion battery technology. Parisbased Saft is a leading global specialist in the design and manufacture of high-tech batteries for industrial applications. It is based in the municipality of Carros in the AlpesMaritimes department, near Nice on the Côte d'Azur. Carros is on the periphery of the French transmission grid, making its electricity supply a structural challenge. Its novel aspect is that energy storage capability is being added to the power distribution system, allowing reserve energy to be made available when needed. It began in January 2012, and run in December 2015. The budget for the Nice Grid project is approximately $€ 30$ million, of which $€ 11$ million is being provided by the French government and the European Union. This smart grid demonstration project is led by ERDF (Electricité Réseau Distribution France). The Nice Grid project is one of six smart grid demonstrations within the large-scale Grid4EU project, which aims to test advanced smart grid solutions with wide replicability and scalability potential for the European market. Grid4EU will test the potential of smart grids in areas such as renewable energy integration, electric vehicle development, grid automation, energy storage, energy efficiency, and load reduction [24].

\subsection{French 1000 km Solar Road Project}

The World's First Solar Road has been in operation in the Netherlands since November 2014. French government plans to pave 1,000 kilometers (621 miles) of its roads with Solar Panels for supplying the electrical power to 5 millions of people, $8 \%$ of the French population. Due to expression from French Agency of Environment and Energy Management, 4 meters of that road could supply one household, excluding heat. One kilometer will supply enough electricity for 5,000 residents. The project is the result of five years research between French road construction company Colas and the French National Institute of Solar Energy. Wattway that introduced in October, 2015 are extremely thin (7 millimeters) durable 15\% efficiency panels of polycrystalline silicon, 15 centimeters wide and heavy-duty skid resistant to reduce auto accidents. Lifetime roughly 20 years if the section is not heavily trafficked. The installations propose to pay for them by raising taxes on fossil fuels. It was natural to raise taxes on fossil fuels given that the oil cost is currently so low, adding that new taxes would contribute between $€ 200-300$ million (\$220-440 million) to the Positive Energy initiative $[25,45]$.

\subsection{Growth in French EV Market}

As reported in Fig. 20, the growths in French Electric Vehicle Market were around $25 \%$ and around $10 \%$ in 2013 and 2014 respectively. However, the growth during 2015 was notable with representing a shift-change for the country. The share of the total French automotive market held by electric vehicles in 2015 was around 1.16\%, according to the most recent figures from EV-Volumes. Year-on-year growth for the 
French electric vehicle market for both all electrics (EVs) and plug-in hybrids (PHEVs) was thus right around 68\%, a substantial increase in 2015. Altogether around 26,550 plug-in vehicles were sold in France in 2015. The large growth in sales during 2015 puts France in eighth place out of the 40 markets tracked by EV-Volumes [26].

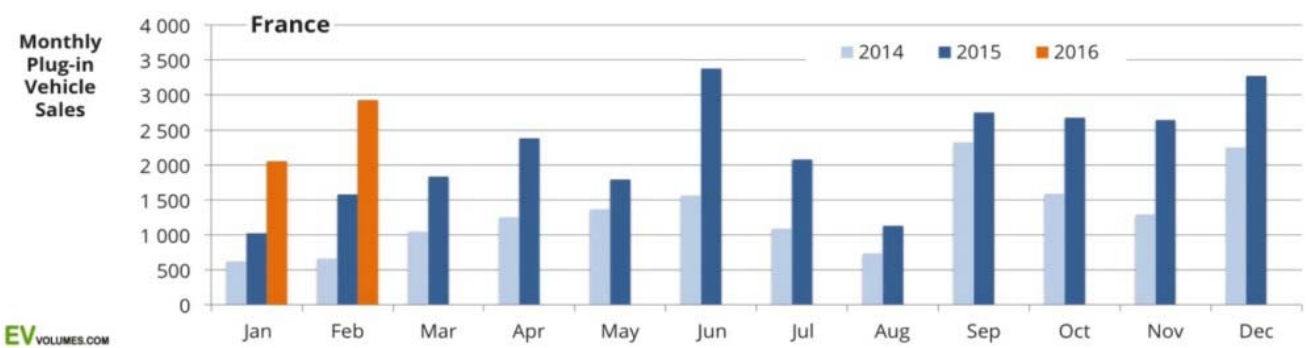

Fig.20 Comparison of French EV Market

\subsection{French RE Statistics}

Times-Series Shares of French RE Generation in total annual electricity consumption is reflected in Fig. 21 [5]. Therefore, 19.5\% of the French power consumed came from renewables in the year 2014. Fig. 22 mentions the French generated capacities (TWh) of different energies in the year 2014. All in all, production from French renewables reached 96.1 TWh [36].

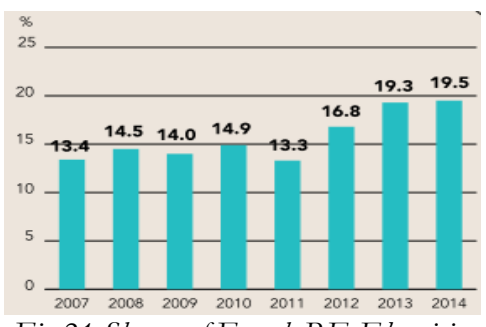

Fig.21 Shares of French RE Electricity

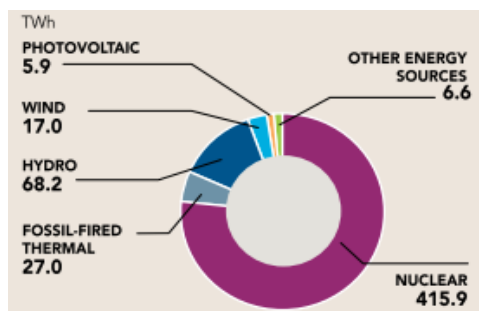

Fig.22 French Generated Capacities in 2014

As a signatory to the Kyoto Protocol, France has developed a new system for support of energy-related research, development, and innovation in the field of RE. RE accounted for $15.3 \%$ of France's total energy production in 2009. Among the objectives of the national energy policy is to raise from $15 \%$ to $21 \%$ the share of the nation's electrical consumption coming from wind, biomass, and hydropower and, by 2015, to achieve a $50 \%$ increase in the production of heat from RE sources [27]. The comparisons of World, Europe and French Yearly MW RE Capacity Statistics from 2006 to 2015 are listed in Table 4. Numbers followed by the letter "o" are figures that have been obtained from official sources such as national statistical offices, government departments, regulators and power companies. The letter " $u$ " follows figures that have been obtained from unofficial sources, such as industry associations and news articles. The letter " $\mathrm{e}$ " follows figures that have been estimated by IRENA from a variety of different data sources [28]. However, these are not considered for the data evaluations in the 6 Section. 
Table 4 Comparisons of World, Europe and French RE Capacity Statistics, 2006-2015 [28]

\begin{tabular}{|c|c|c|c|c|c|c|c|c|c|c|}
\hline & 2006 & 2007 & 2008 & 2009 & 2010 & 2011 & 2012 & 2013 & 2014 & 2015 \\
\hline \multicolumn{11}{|c|}{ Total Renewables } \\
\hline World & 1036694 & 1094352 & 1164288 & 1251978 & 1348000 & 1456665 & 1570533 & 1697567 & 1833501 & 1985074 \\
\hline Europe & 272948 & 285615 & 302474 & 324466 & 352903 & 390002 & 424431 & 451039 & 472979 & 497378 \\
\hline France & 28104 & 28983 & 30144 & 31592 & 33908 & 36568 & 38634 & 39935 & 41788 & 44274 \\
\hline \multicolumn{11}{|c|}{ Total Hydropower } \\
\hline World & 892904 & 924541 & 957899 & 992927 & 1027634 & 1057997 & 1090905 & 1135580 & 1173467 & 1208949 \\
\hline Europe & 199411 & 201330 & 202737 & 204316 & 207851 & 209353 & 210286 & 212263 & 213331 & 214947 \\
\hline France & 25117 & 25129 & 25097 & 25185 & 25332 & 25347 & 25366 & 25443 & 25294 & 25421 \\
\hline \multicolumn{11}{|c|}{ Small hydropower $(<1 \mathrm{MW})$} \\
\hline World & 29267 & 29296 & 29338 & 29502 & 30477 & 29869 & 29709 & 27228 & 27605 & 30785 \\
\hline Europe & 2937 & 2966 & 2961 & 3097 & 4051 & 3344 & 3428 & 3513 & 3565 & 3633 \\
\hline France & 433 & 436 & 443 & 447 & 1271 & 432 & 429 & 417 & $415 \mathrm{o}$ & $415 \mathrm{e}$ \\
\hline \multicolumn{11}{|c|}{ Medium hydropower (1-10 MW) } \\
\hline World & 67566 & 71251 & 75601 & 79779 & 85094 & 89958 & 95033 & 102779 & 107045 & 114395 \\
\hline Europe & 10051 & 10374 & 10654 & 11146 & 12026 & 11771 & 11915 & 12170 & 12308 & 12516 \\
\hline France & 1610 & 1617 & 1627 & 1628 & 2287 & 1589 & 1596 & 1604 & $1614 \mathrm{o}$ & $1614 \mathrm{e}$ \\
\hline \multicolumn{11}{|c|}{ Large hydropower (>10 MW) } \\
\hline World & 677570 & 701342 & 727881 & 753323 & 779151 & 801445 & 818137 & 855985 & 888385 & 910242 \\
\hline Europe & 138061 & 139426 & 140057 & 140047 & 141514 & 143729 & 144255 & 145519 & 145788 & 146548 \\
\hline France & 15777 & 15779 & 15852 & 15935 & 14529 & 16081 & 16096 & 16177 & $16100 \mathrm{o}$ & $16227 \mathrm{e}$ \\
\hline \multicolumn{11}{|c|}{ Pumped Storage and Mixed Plants } \\
\hline World & 118500 & 122653 & 125080 & 130323 & 132912 & 136725 & 148025 & 149588 & 150432 & 153526 \\
\hline Europe & 48362 & 48565 & 49065 & 50026 & 50261 & 50510 & 50689 & 51062 & 51670 & 52251 \\
\hline France & 7297 & 7297 & 7175 & 7175 & 7245 & 7245 & 7245 & 7245 & 7165 o & $7165 \mathrm{e}$ \\
\hline \multicolumn{11}{|c|}{ Marine Energy } \\
\hline World & 265 & 266 & 266 & 269 & 271 & 526 & 530 & 529 & 522 & 547 \\
\hline Europe & 241 & 241 & 241 & 243 & 244 & 245 & 249 & 248 & 242 & 264 \\
\hline France & 240 & 240 & 240 & 240 & 240 & 240 & 240 & 240 & 240 o & $241 \mathrm{e}$ \\
\hline \multicolumn{11}{|c|}{ Onshore Wind Energy } \\
\hline World & 72622 & 92613 & 118179 & 156259 & 193138 & 232752 & 277187 & 310831 & 360296 & 419787 \\
\hline Europe & 47398 & 55705 & 63559 & 73699 & 82168 & 91452 & 102406 & 112235 & 122513 & 132669 \\
\hline France & 1700 & 2492 & 3530 & 4676 & 5975 & 6810 & 7622 & 8202 & 9068 o & $10358 \mathrm{u}$ \\
\hline \multicolumn{11}{|c|}{ Solar Photovoltaic } \\
\hline World & 6065 & 8621 & 14553 & 22386 & 38818 & 68986 & 97349 & 136751 & 175362 & 222360 \\
\hline Europe & 3318 & 5277 & 10429 & 16785 & 29543 & 51750 & 69619 & 81154 & 88315 & 95916 \\
\hline France & 15 & 26 & 80 & 263 & 1030 & 2803 & 3953 & 4625 & 5654 o & 6549 o \\
\hline \multicolumn{11}{|c|}{ Bioenergy } \\
\hline World & 54073 & 56885 & 61067 & 66477 & 72720 & 79920 & 85202 & 90930 & 98277 & 103530 \\
\hline Europe & 20569 & 20786 & 22713 & 25694 & 28007 & 31066 & 33373 & 34471 & 36790 & 38637 \\
\hline France & 1032 & 1096 & 1197 & 1228 & 1331 & 1366 & 1451 & 1423 & 1530 & 1703 \\
\hline \multicolumn{11}{|c|}{ Solid Biofuels and Renewable Waste } \\
\hline World & 48217 & 50051 & 53571 & 57560 & 62554 & 68075 & 71380 & 76498 & 82630 & 87344 \\
\hline Europe & 16594 & 16185 & 17543 & 19403 & 20694 & 22400 & 23247 & 23962 & 25013 & 26497 \\
\hline France & 942 & 989 & 1070 & 1069 & 1160 & 1160 & 1204 & 1150 & $1210 \mathrm{o}$ & $1340 \mathrm{o}$ \\
\hline \multicolumn{11}{|c|}{ Renewable Municipal Waste } \\
\hline World & 9912 & 9754 & 10124 & 10810 & 11150 & 11313 & 11461 & 12412 & 12689 & 12912 \\
\hline Europe & 5381 & 5149 & 5503 & 6123 & 6410 & 6483 & 6517 & 7386 & 7578 & 7737 \\
\hline France & 729 & 744 & 819 & 821 & 807 & 852 & 900 & 825 & $830 \mathrm{o}$ & $872 \mathrm{o}$ \\
\hline \multicolumn{11}{|c|}{ Other Solid Biofuels } \\
\hline World & 27691 & 29223 & 31245 & 34947 & 39103 & 43063 & 44684 & 47160 & 51686 & 54864 \\
\hline Europe & 11214 & 11037 & 12041 & 13281 & 14284 & 15917 & 16730 & 16576 & 17435 & 18760 \\
\hline France & 213 & 245 & 251 & 248 & 353 & 308 & 304 & 325 & $380 \mathrm{o}$ & 468 o \\
\hline & & & & & Biogas & & & & & \\
\hline World & 5458 & 6340 & 6828 & 7833 & 8845 & 10439 & 12223 & 12882 & 13660 & 14214 \\
\hline Europe & 3644 & 4181 & 4583 & 5390 & 6262 & 7530 & 8819 & 9201 & 10032 & 10410 \\
\hline France & 90 & 107 & 127 & 159 & 171 & 206 & 247 & 273 & $320 \mathrm{o}$ & 363 o \\
\hline & & & & & othermal $\mathrm{E}$ & ergy & & & & \\
\hline World & 9472 & 9853 & 10316 & 10722 & 10970 & 10926 & 11306 & 11691 & 12482 & 13089 \\
\hline Europe & 1120 & 1185 & 1274 & 1301 & 1334 & 1426 & 1439 & 1446 & 1485 & 1554 \\
\hline France & 0 & 0 & 0 & 0 & 0 & 2 & 2 & 2 & 20 & $2 \mathrm{e}$ \\
\hline
\end{tabular}




\section{Results and Discussions}

\subsection{Times Series Analysis of French RE Scenarios During 2006 to 2015}

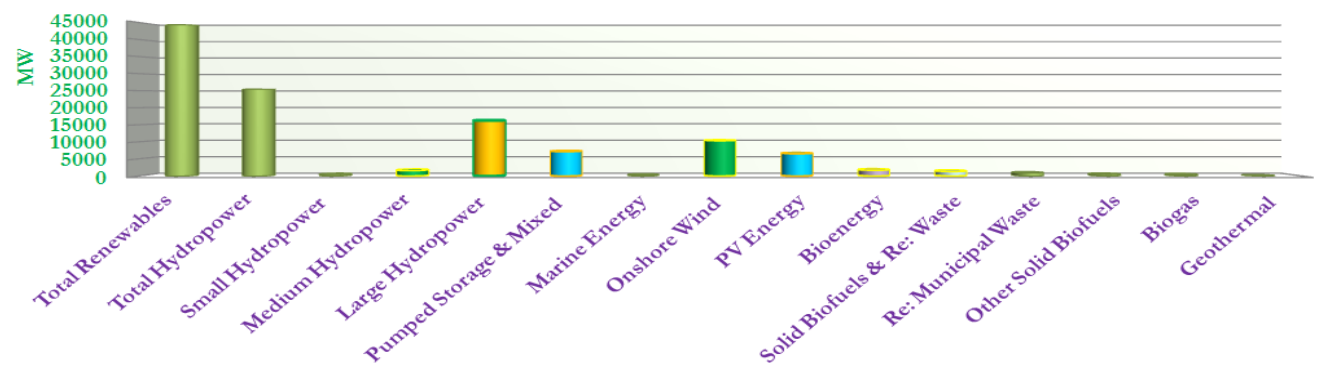

Fig.23 Scenario of French RE Capacity (MW) in 2015

Based on the Statistics (Times Series Data) of Table 4, a Scenario of French RE capacity (MW) in the year 2015 is depicted with the column chart (3-D Cylinder) as highlighted in Fig. 23. It is obvious that the Large Hydropower Generation Systems contributes the largest capacity and Onshore Wind Power constitutes the second largest portion. Solar PV Energy, Pumped Storage and Mixed Plants are also playing significant role in French 2015 RE Scenario.

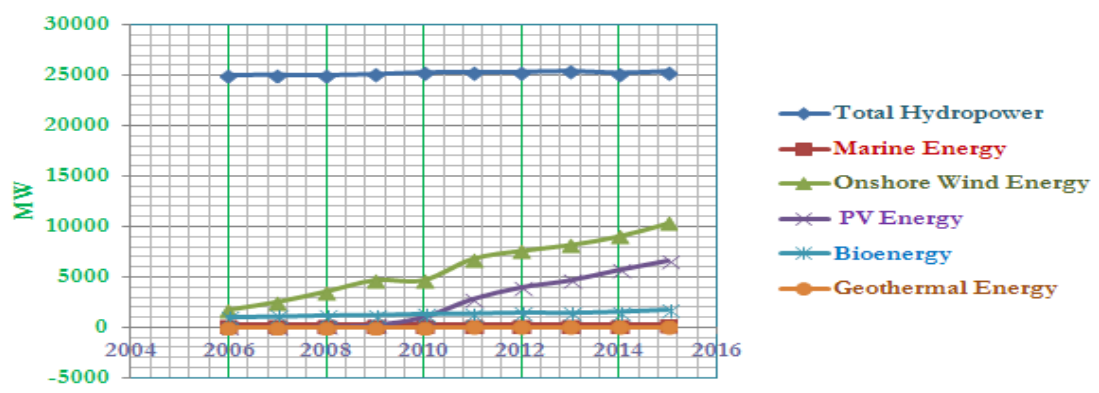

Fig.24 French RE Trends (MW) during 2006 to 2015

Again, French RE trends during the year 2006 to the year 2015 are demonstrated in Fig. 24 (XY Scatter). From it, it is observed that there are two major trends of French RE Scenarios such as rise trend and stable trend. Onshore Wind Energy reflects the former trend that was begun in 2006 and stable (no increase but a little decrease) between the year 2009 and the year 2010. Then, it was regularly raised year by year. Significant promotion of French PV trend was started in the year 2009 and obviously accelerated in the year 2010. From Fig. 24, it can be obviously seen that the French PV Trend is parallel with Onshore Wind Energy Trend. On the other hand, French Hydropower is involving as the highest trend in all RE that is actually the second largest in EU. However, its trend is stable throughout the year 2006 to 2015. Bioenergy, Marine Energy and Geothermal Energy are very low contributions and also stable trends similar with Hydropower trend during the last 10 years. 
Table 5 Promotions of French RE Powers (MW) in 2006, 2010 and 2015

\begin{tabular}{|c|c|c|c|}
\hline $\begin{array}{l}\text { Sr } \\
\text { No. }\end{array}$ & $\begin{array}{l}\text { French } 2006 \text { RE } \\
\text { Mix }\end{array}$ & French 2010 RE Mix & French 2015 RE Mix \\
\hline 1. & $\begin{array}{l}\text { Total Hydropower } \\
\text { (25117 MW) }\end{array}$ & $\begin{array}{l}\text { Total Hydropower } \\
\text { [ } 25332 \text { MW, } \\
\text { (215 MW Promoted in 2006-2010)] }\end{array}$ & $\begin{array}{l}\text { Total Hydropower } \\
\text { [ } 25421 \text { MW, } \\
\text { ( } 89 \text { MW Promoted in 2010-2015)] }\end{array}$ \\
\hline 2. & $\begin{array}{l}\text { Onshore Wind } \\
\text { Energy } \\
(1700 \mathrm{MW})\end{array}$ & $\begin{array}{l}\text { Onshore Wind Energy } \\
\text { [ } 4676 \mathrm{MW} \text {, } \\
(2976 \mathrm{MW} \text { Promoted in } 2006-2010)]\end{array}$ & $\begin{array}{l}\text { Onshore Wind Energy } \\
\text { [ } 10358 \mathrm{MW} \text {, } \\
\text { (5682 MW Promoted in 2010-2015)] }\end{array}$ \\
\hline 3. & $\begin{array}{l}\text { Bioenergy } \\
(1032 \mathrm{MW})\end{array}$ & $\begin{array}{l}\text { Bioenergy } \\
\text { [1331 MW, } \\
(299 \text { MW Promoted in 2006-2010)]..* }\end{array}$ & $\begin{array}{l}\text { PV Energy } \\
\text { [ } 6549 \text { MW, } \\
\text { (5519 MW Promoted in 2010-2015)] }\end{array}$ \\
\hline 4. & $\begin{array}{l}\text { Marine Energy } \\
(240 \mathrm{MW})\end{array}$ & $\begin{array}{l}\text { PV Energy } \\
\text { [1030 MW, } \\
(1015 \text { MW Promoted in 2006-2010)] }\end{array}$ & $\begin{array}{l}\text { Bioenergy } \\
\text { [ } 1703 \text { MW, } \\
\text { (372 MW Promoted in 2010-2015)] }\end{array}$ \\
\hline 5. & $\begin{array}{l}\text { PV Energy } \\
(15 \mathrm{MW})\end{array}$ & $\begin{array}{l}\text { Marine Energy } \\
(240 \mathrm{MW})\end{array}$ & $\begin{array}{l}\text { Marine Energy } \\
\text { [241 MW, } \\
\text { (1 MW Promoted in 2010-2015)] }\end{array}$ \\
\hline 6. & $\begin{array}{l}\text { Geothermal Energy } \\
(0 \mathrm{MW})\end{array}$ & $\begin{array}{l}\text { Geothermal Energy } \\
(0 \mathrm{MW})\end{array}$ & $\begin{array}{l}\text { Geothermal Energy } \\
\text { [ } 2 \text { MW, } \\
\text { (2 MW Promoted in 2010-2015)] }\end{array}$ \\
\hline
\end{tabular}

Table 5 highlights the promotions of French RE Powers (MW) in RE Mix of the years 2006, 2010 and 2015. It is also listed with the largest to the smallest Powers. Although all powers are increased, the two largest contributions of Energy Types are not changed. From 2006 to 2015, French largest RE Share is Hydropower. However, its increased Powers is 215 MW during the 5-year (2006-2010). It is just 89 MW promoted from 2010 to 2015 . Totally, it is only 304 MW promoted during the 10-year period.

From Table 5, Onshore Wind Energy is taken as the second largest share in French RE Share Mix between the years 2006 to 2015. 2976 MW of Onshore Wind is promoted from the years 2006 to 2010 and it is significantly 5682 MW promoted during the year 2010 to the year 2015. Therefore, its total increment is 8658 MW and it is notably highest French RE promotion during the last 10-year. The third largest role of French RE is accommodated by Bioenergy. However, it is replaced by surprised rise of PV, 15 MW in 2006 to 6549 MW in 2015. French Bioenergy is still seated at the fourth main RE with just increased power of 671 MW for 10 years from 2006 to 2015 . Marine Energy and Geothermal Energy cannot show the significant rise in the last 10 years.

For more obvious observation of comparison between French RE Mix in the last 10 years, 3-D pie charts of Fig.25 is illustrated. Hydropower shared about $89 \%$ in French 2006 RE Mix. This share is dropped till $57 \%$ in French 2015 RE Mix. This Decreased proportions $(32 \%)$ was occupied by the combination of Onshore Wind Energy $(23 \%, 17 \%$ rise) and PV Energy (15\%) in the year 2015. In addition, French RE Shares (As \%) in World RE Capacities and EU RE Capacities are contributed as Low Scenarios during the previous 10 years as demonstrated with Fig.26 and Fig.27(3-D cylinder charts). 

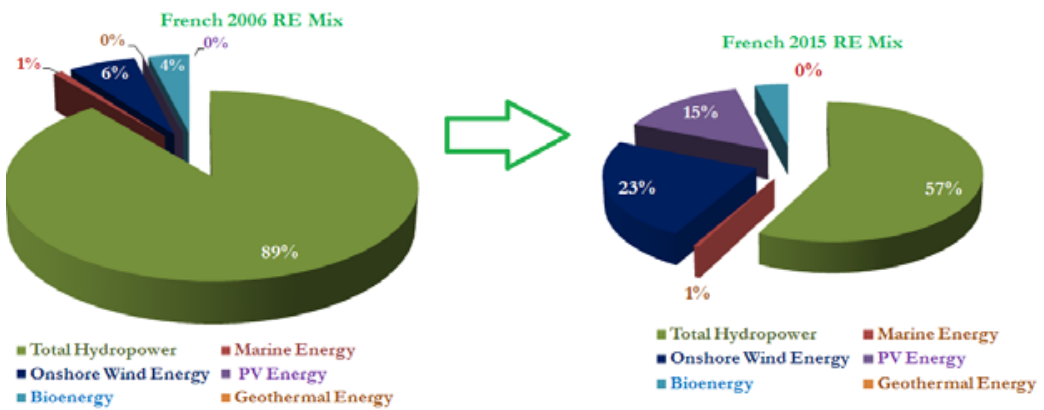

Fig.25 Comparison of RE Shares (\%) between French 2006 RE Mix and French 2015 RE Mix

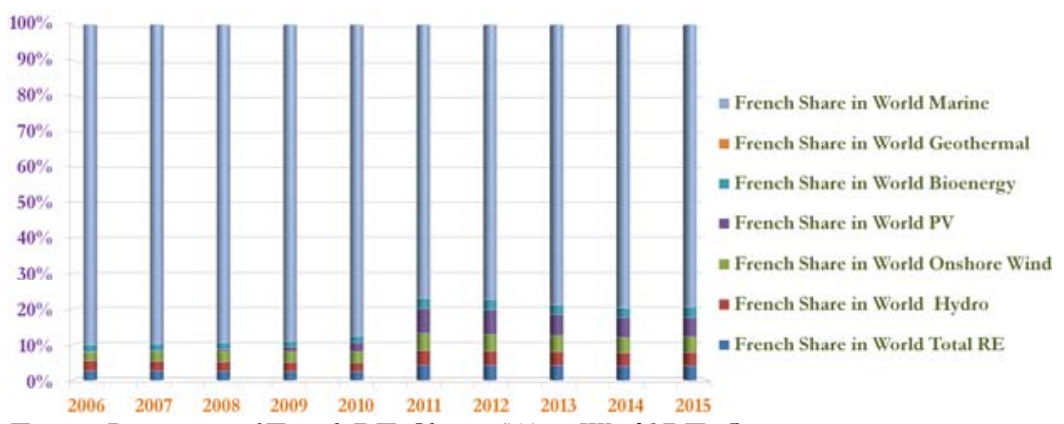

Fig. 26 Proportion of French RE Shares (\%) in World RE Capacities

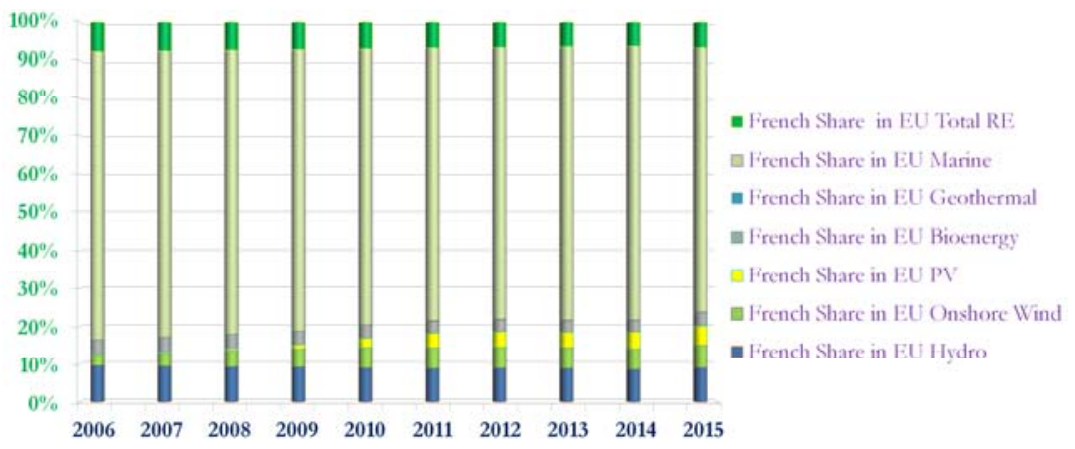

Fig. 27 Proportion of French RE Shares (\%) in EU RE Capacities

\subsection{Situation of French and EU Offshore Wind}

The important discussion point is dealt with the situation of French Offshore Wind. France enriches the massive Wind Energy Potential by the coastlines on the English Channel, Atlantic Ocean and Mediterranean Sea. According to the Syndicat des Energies Renouvelables, it is estimated about 90 TWh [29]. Capacities of Offshore Wind Power of World (12161 MW) and (EU 11082 MW) by 2015 are reflected as in Fig. 28. 


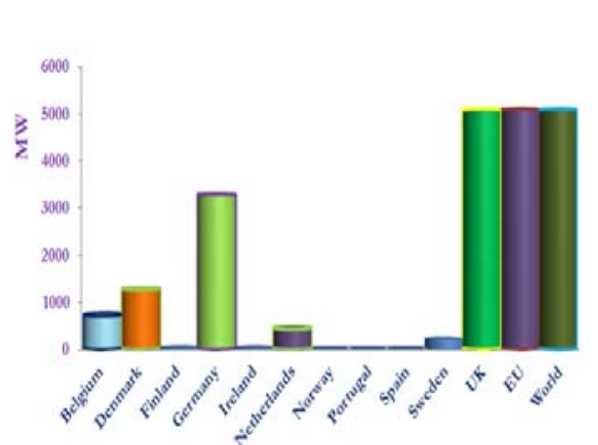

Fig.28 EU Offshore Wind Capacities in 2015

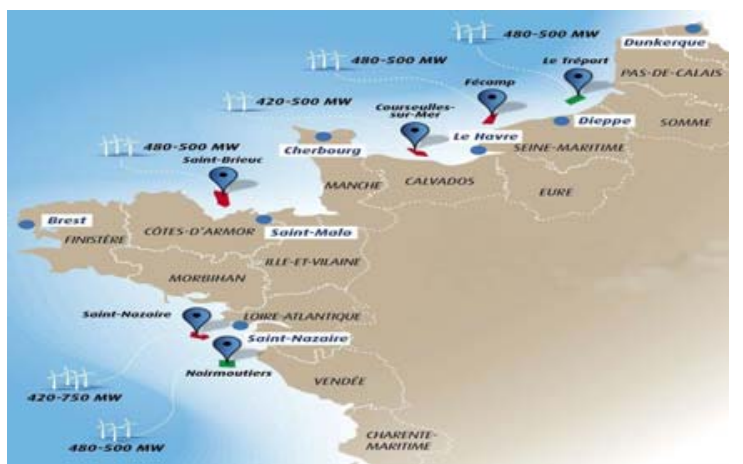

Fig.29 French First and Second Offshore Wind Tenders

There are $11 \mathrm{EU}$ countries that have Offshore Wind. French eastern neighbor, Germany contributed as the second largest Offshore Wind Power (3295 MW) with approximately $30 \%$ in EU Offshore Wind as well as $27 \%$ in World Offshore Wind. Also, UK contributed as the largest Offshore Wind (5105 MW) of both EU (46\% share) and as well as in World (42\% share) in the year 2015 [28]. Although there is no evidence for existing French Offshore Wind development, France has the 6 GW Offshore Wind Target by 2020. For this target, as mentioned in [29], the equivalent of 1,200 wind turbines to be built and installed off the coast of France. In the first week of April, 2016, France announced its third Offshore Wind tender for an area off the coast of Dunkirk, in the country's north [30]. French first tender for a total of 2 GW Offshore Wind was offered in 2012, representing an investment of around $€ 7$ billion. The second $1 \mathrm{GW}$ tender was offered in 2014 and an investment of around $€ 4$ billion. French Offshore Wind tender zones identified by first round tender zones in Red and second tender zones in green are referenced from Ministry of Ecology, Sustainable Development and Energy and shown as Fig.29 [31].

\subsection{Situation of French Domestic Solar Thermal Market}

Although there were renewed encouragements by professionals in the French solar thermal market to improve it, 2014 proved as another difficult year. The overall installed area of solar thermal collectors fell by $21 \%$ from $190900 \mathrm{~m}^{2}\left(133.6 \mathrm{MW}_{\text {th }}\right)$ to $150500 \mathrm{~m}^{2}\left(105.4 \mathrm{MW}_{\text {th }}\right)$. In the residential market, solar water heaters took $18 \%$ drop in terms of collector area $\left(-15000 \mathrm{~m}^{2}\right)$. The number of installed units decreased less dramatically $(-9 \%)$ due to average collector area per unit installed has been falling over recent years. The market of combined solar water and space heaters contracted strongly both in terms of units $(-36 \%)$ and area $(-30 \%)$. Non-domestic sales were down by $22.6 \%$ with a total solar thermal collector area amounting to $75500 \mathrm{~m}^{2}$ (53 $\mathrm{MW}_{\text {th }}$ ). Expected changes in the current regulation for thermal requirements in new buildings were not implemented in 2015 as planned. French solar thermal market will be suffering in the coming months, although an action plan has been put together to enhance consumer trust and help with market structuring over the next three years [32]. 


\subsection{Comparison of French PV with EU Neighbors}

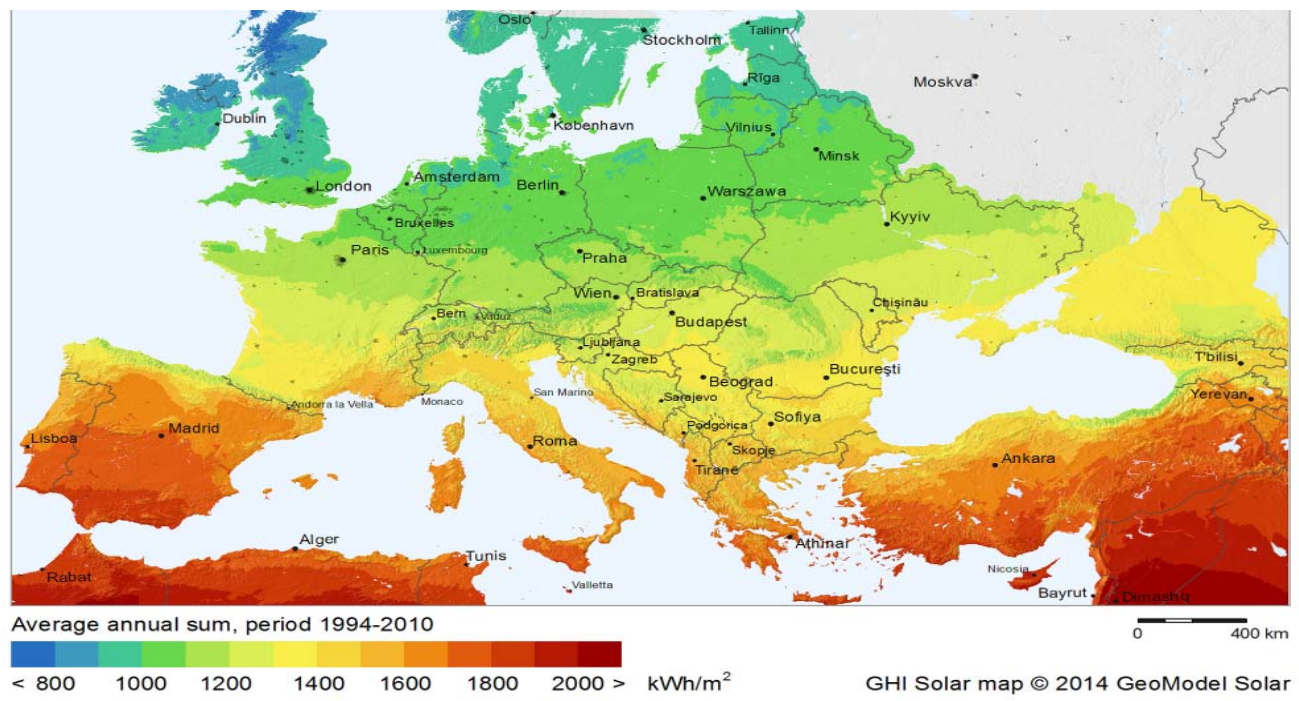

Fig.30 Global Horizontal Irradiation (GHI) of Europe [39]

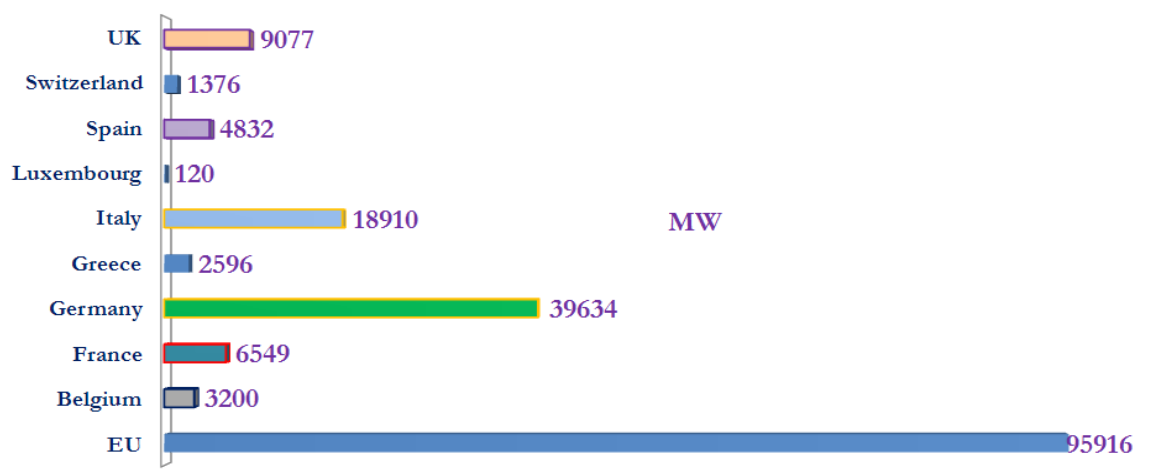

Fig.31 PV Capacities of EU in 2015

Global Horizontal Irradiation (GHI), the most important parameter of PV electricity, of Europe is mentioned in Fig. 30. As informed in [28], PV Capacities of total EU and some countries are depicted in Fig. 31. Although GHI of Germany is lesser than France, its PV Capacit is 33085 MW greater than France PV. Germany contributed as over $41 \%$ share in EU PV Capacity and approximately $18 \%$ share in World PV Capacity. It can be easily seen that in spite of lesser GHI in UK, its PV Capacity is the third greatest in EU and $2528 \mathrm{MW}$ greater than Franch PV. The another French neighbor, Italy also 12361 MW greater than French PV Capacity. However, France contributed PV 1717 MW greater than its sounthern neighbor, Spain that enriches higher PV potential than France.

\subsection{Outlook of French RE Development}

Although the existing French RE scenario is low, France has significantly large RE Capacity Targets in the near future. French government will publish the decree in a few weeks' time, outlining ambitious renewable energy proposals that include solar 
capacity to nearly triple and onshore wind capacity to more than double by 2023. France has the plans to boost Onshore Wind Capacity from around $15000 \mathrm{MW}$ end 2018 to up to 25,000 by 2023 and for PV, targets increased from $10200 \mathrm{MW}$ by end of 2018 to $30000 \mathrm{MW}$ by the end of 2023. In addition, modest targets for a few 100MW of other clean energy technologies [33]. However, it is notable that these targets are still smaller than the Germany PV Capacity (39634 MW) and Germany Onshore Wind Capacity (41652 MW) by 2015 according to [28]. According to French 2020 REAP, France targets $27 \%$ RE Electricity by the year 2020. Also due to French NREAP (Energy Transition Act), France targets $40 \%$ Electricity Generation from RE by 2030. The predominant point is 100\% RE Electricity is possible in France by 2050 as highlighted in [34].

\section{Conclusions}

The World is suffering the serious negative impacts from previous GHG emissions by human activities. The United Nations Framework Convention on Climate Change (UNFCCC) Conference has been yearly delegating since 1995 in Berlin, Germany as COP 1. UN 2030 Agenda formulates a set of 17 Sustainable Development Goals (SDGs) to end poverty, fight inequality and injustice, and tackle climate change by 2030. The most recent historically Climate Agreement is Paris 2015 (COP21).

EU is impressively leading the Global fight against climate change. EU has set itself some of the world's most ambitious climate as well as strategic energy targets. Border-by-border electricity trade analysis reflects the growing impact of changes in the EU energy mix by integrating of more and more renewables.

EU has developed the world's largest company-level EU Emissions Trading System (EU ETS). EU has committed to cut its GHG emissions to $20 \%$, $40 \%$ and 80$95 \%$ below 1990 levels by 2020, 2030 and 2050 respectively. RE technologies have the potential to spur sustainable development if implementation follows the principles of benefits sharing, biodiversity, equality, job creations and decentralizations. RE and EE are predominant weapons of climate change adaptation, improving the resilience of existing energy systems and ensuring delivery of energy services under climatic change. So, EU 2020 targets adopted as $20 \%$ RE Share and $20 \%$ improvement in EE by 2020. Also, EU 2030 targets identified as 27 \% RE Share and 27 \% Energy Savings by 2030.

The notable messages are highlighted regarding French Green Boost Paradigm:

- France is actively and effectively participating with strong institutions in Green Paradigm of World and EU. France is proving it by boosting RE deployments with its distinguished incentive mechanisms (Feed-in-Tariffs, FIT) as well as implementing NREAP, Green Innovation, Energy Transition Act and LowCarbon Economy.

- France is leading the EU Electricity exporter and also attempting to decrease the dependency on Nuclear Energy.

- French RE accounted for nearly 20\% of power consumption in 2014. Realistically, this amount is dealt with the French Hydropower contribution that is the second largest in EU after Norway.

- In French RE scenario, there are only four key players, Solar Photovoltaic (PV), Onshore Wind, Hydropower and Bioenergy. 
- France is blessed with tremendous Offshore Wind Potential. Offshore Wind Power may be Surprise Game Changer for French RE promotion. Therefore, more rapid mobility of Offshore Wind Developments should be prioritized.

- France is aspiring to become a leader in Carbon-Free technologies especially by PV technologies. In spite of short accelerating period of French PV Generation since 2010, France has the pioneer PV projects of EU. However, the existing and near future PV Capacities are still lower than the PV Capacities of Germany, EU PV Leader that enriches significantly lesser PV Potential than France.

- France Onshore Wind and PV Capacities are promoting steeply in parallel and it is expected as their Trends will cut the stable Hydropower Trend. Due to French targets, Onshore Wind Capacity will be nearly meet the Hydropower Capacity and also PV Capacity will be approximately about 5000 MW greater than Hydropower Capacity in the year 2023. There are more increments of Onshore Wind and PV Energy Capacities are needed to upgrade French RE.

- For more penetration of French RE, the encouragement of Grid Connected RE Systems and strategic deployment of Off-Grid PV Hybrid Microgrids could be the feasible solutions.

- Domestic Solar Thermal Market should be also enhanced.

- The spectacular growth of French EV Market highlights the successful outcome from the strategies to reduce the GHG emissions from Transportation, the source of country's largest GHG emissions.

All in all, it can be concluded that French Green Icons (Lyon Smart Community, 300 MW Europe's Largest Solar Park, Nice Smart PV Grid Project and $1000 \mathrm{~km}$ French Solar Road Project), Offshore Wind Tenders and encouragement of PV investment are evidently reflecting the French Green Boost Paradigm is in line with EU strategic targets towards Global SDGs.

\section{Acknowledgements}

First of all, the author offers the deepest acknowledges to his father, U Sein Hla (Ret. Executive Engineer, Author, Accountant in Charge and CEC member of Myanmar Writers Association) and his mother, Daw Htway Lay for their infinite encouragements.

The author reports deeply gratitude to U Kyaw Zwa Soe (Director General, Department of Technology Promotion and Cooperation, Ministry of Education, Myanmar) for his kind permission. Especially, the author is grateful to Dr. Myint Thein (Rector of Mandalay Technological University, Myanmar) for his kind instruction. The author thanks to Dr. Yan Aung Oo (Professor and Head, Department of Electrical Power Engineering, Mandalay Technological University) for his kind help. The author appreciates to Prof. Dr. Cécile Belleudy [LEAT, University of Nice-Sophia Antipolis (UNS), France] for her advices. The author offers his gratitude to Prof. Dr. Francine Diener (EMMA Coordinator, UNS), Ms. Virginie Oddo (Administrative Service Manager, UNS) and Ms. Julie Guillaumat (EMMA Project Manager, UNS) for their supports in EMMA Project. The author sincerely thanks to Dr. Srdjan Redzepagic (Professor of Economics, ISEM, UNS, France) for his kind support.

Moreover, the author mentions special acknowledges to Dr. Peter Lilienthal (CEO of HOMER Energy, USA) for his excellent guidance and support. The author is 
deeply grateful to Prof. Dr. Jose Carlos de Oliveira (UNESCO Collaborator, EMMA Coordinator, Department of Mathematics, University of Evora, Portugal) for sharing his invaluable experiences and impressive advices. The author presents sincere appreciations to Prof. Dr. Prince G. Gadama (2 ${ }^{\text {nd }}$ Vice Chancellor, Board of Directors, Cypress International Institute, Texas, USA) for his kind support. The last but not least, the author offers the heartfelt thanks to his family for their valuable encouragements.

\section{References}

[1] Renewable Energy Policy Network for the 21st Century (REN21). (2015). Renewables 2015 Global Status Report, Annual Reporting on Renewables: Ten years of Excellence. Paris, France.

[2] European Commission (EU). (November 2015). Climate Change Fact sheet, EU Publications Office.

[3] MEDDE (Ministry of Ecology, Sustainable Development and Energy), SOeS (General Directorate for Sustainable Development), SCEE (General Directorate for Energy and Climate) and I4CE (Institute for Climate Economics). (2016). Highlights: Key Figures on climate France and worldwide 2016 Edition. I4CE Paris, France.

[4] International Renewable Energy Agency (IRENA). (2015). REthinking Energy: RE and Climate Change. Abu Dhabi, United Arab Emirates. IRENA Headquarters.

[5] Rte. (2015). Press kit: France Electricity Report for 2014. Rte Press. Paris, France.

[6] www.rolandberger.fr

[7] http://www.power-to-the-people.net/2015/09/how- renewable- energy- help-achieving-thesustainable-development-goals/.

[8] ICSU, ISSC (2015): Review of the Targets for Sustainable Development Goals: The Science Perspective. Paris: International Council for Science (ICSU).

[9] International Renewable Energy Agency (IRENA). (June 2014.). REmap 2030: A RE Roadmap. Abu Dhabi, United Arab Emirates. IRENA Headquarters.

[10] http://www.triplepundit.com/2016/04/cheat-sheet-paris-agreementsigning ceremony/

[11] http://www.elsastravelblogonparis.com/earth-day-2016-signing-of-paris-climate agreement-at$\underline{\text { the-u-n/ }}$

[12] European Commission (EU). (2016). EU Climate Action: 2020 Climate \& Energy Package. Source: http://ec.europa.eu/clima/policies/strategies/2020/index en.htm

[13] https://ec.europa.eu/energy/sites/ener/files/documents/2014 eec communication adopted $\underline{0 . p d f}$

[14] European Commission (EU). (9 April 2014). New Rules and Guidelines for Environmental Protection and Energy (IP/14/400), Brussels, Belgium.

[15] European Commission (EU). (2016). EU Energy: 2030 Energy Strategy. Source: http:// ec.europa.eu/ energy/en/topics/energy-strategy/2030-energy-strategy

[16] https://www.transportenvironment.org/sites/te/files/2015TEcarsCO2reportFINAL.pdf

[17] http://www.transportenvironment.org/what-we-do/cars-and-co2/publications

[18] European Commission (EU). (2016). EU Climate Action: 2050 Low Carbon Economy. Source: http://ec.europa.eu/clima/policies/strategies/2050/index en.htm

[19] International Energy Agency (IEA). (2014). France Renewable Energy Polices. Source: http://www.iea.org/policiesandmeasures/renewableenergy/?country =France

[20] http://www. economie. grandlyon. com/fileadmin/user upload/fichiers/site eco/ 20121121 gl lyon smart community dp en.pdf

[21] http:// www.neoen.fr/wp-content/ uploads/2014/11/Neoen-Cestas-solar-park-1106.pdf

[22] http://www.pv-magazine.com/news/details/beitrag/neoen-breaks-ground-on-300-mw-frenchsolar-plant 100017099/

[23] http:// www.treehugger. com/ renewable-energy/europes-largest-solar-park-officially-openscommemorate-paris- climate-change-talks.html

[24] http://www.renewableenergyfocus. com/view/41910/ nice-grid-smart-grid-project-uses-saftenergy-storage-with-solar-power-in-south-of-france/

[25] http://ecowatch.com/2016/02/01/wattway-solar-road/ 
[26] http://cleantechnica.com/2016/04/07/french-ev-marketshare-hit-1-16-in-2015-with 2016sales-to-date-rising-fast/

[27] Campus France. (2011). Renewable Energy Research in France. Source: campusfrance.org

[28] International Renewable Energy Agency (IRENA). (April, 2016) Renewable Energy Capacity Statistics 2016. Abu Dhabi, United Arab Emirates. IRENA Headquarters.

[29] http:// www.areva.com/EN/ operations- 4427/offshore-wind-energy-in-france.html

[30] http:// cleantechnica.com/2016/04/06/france-unveils-third-offshore-wind-tender/

[31] http://www.offshorewindindustry.com/news/french-connection

[32] European Solar Thermal Industry Federation (ESTIF). (June 2015). Solar Thermal Markets in Europe Trends and Market Statistics 2014. Brussels, Belgium.

[33] http://www.pv-tech.org/news/french-solar-capacity-to-nearly-triple-by-2023

[34] http://energytransition.de/2015/04/suppressed-french-report-says-100-renewables- $\quad$ ispossible/

[35] http:// ec.europa. eu /energy/en/topics /energy- efficiency

[36] http://www.rte-france.com/sites/default/files/bilan electrique 2014 en.pdf

[37] http://www.developpement-durable.gouv.fr/IMG/pdf/2016-04 25 International $\underline{\text { Solar Alliance. pdf }}$

[38] https://unfccc.int/resource/docs/2015/cop21/eng/109r01.pdf

[39] http://solargis.info/doc/ pics/freemaps/1000px/ghi/SolarGIS-Solar-map-Europe-en.png

[40] https://sustainable development.un.org/ rio20. html

[41] http://newsroom.unfccc. int/climate-action/25-countries-pledge-to-facilitate-usd-1-trillion-ofinvestment-in-solar/ 